\title{
Palaeoecological and palaeoclimatic conditions on the Karelian Isthmus (northwestern Russia) during the Holocene
}

\author{
Larisa Nazarovaa,b,c* (1), Liudmila S. Syrykh ${ }^{c, d}$, Roseanna J. Mayfield ${ }^{\mathrm{e}}$, Larisa A. Frolovac ${ }^{\mathrm{c}}$, Aisylu G. Ibragimova ${ }^{\mathrm{c}}$, \\ Ivan M. Grekov ${ }^{d}$, Dmitry A. Subetto ${ }^{\text {d,f,g }}$ \\ ${ }^{\text {a} P o t s d a m ~ U n i v e r s i t y, ~ I n s t i t u t e ~ o f ~ G e o s c i e n c e s, ~ A m ~ N e u e n ~ P a l a i s ~ 10, ~} 14469$ Potsdam, Germany \\ ${ }^{\mathrm{b}}$ Alfred Wegener Institute, Helmholtz Centre for Polar and Marine Research, Research Unit Potsdam, Telegrafenberg A43, 14473 Potsdam, Germany \\ ${ }^{\mathrm{c}}$ Kazan Federal University, Kremlyovskaya street 18, 420018 Kazan, Russia \\ ${ }^{\mathrm{d}}$ Herzen State Pedagogical University of Russia, St. Petersburg, 191186 Russia \\ ${ }^{\mathrm{e}}$ Geography and Environmental Science, University of Southampton, Southampton, SO17 1BJ, UK \\ ${ }^{\mathrm{f}}$ Immanuel Kant Baltic Federal University, A. Nevsky street 14, Kaliningrad, 236016, Russia \\ ${ }^{\mathrm{g}}$ Institute for Water and Environmental Problems, Siberian Branch of the Russian Academy of Sciences, Barnaul, Molodezhnaya street 1, 6560386 Russia \\ *Corresponding author e-mail address: Larisa.nazarova@ awi.de (L. Nazarova).
}

(Received March 29, 2019; AcCePTed December 18, 2019)

\begin{abstract}
The Holocene evolution of climate in easternmost Fennoscandia and adjoining regions is poorly known, compared with regions to the west. To address this, a 224-cm-long sediment core from Lake Medvedevskoe, situated on the Central Upland of the Karelian Isthmus, northwestern Russia, was examined to investigate variations in the Holocene climate. Analyses indicate that the dry and cold late Pleistocene climate was replaced by the warmer and more humid early Holocene climate after ca. $10.5 \mathrm{cal}$ ka BP. During the early Holocene, the lake transitioned from an oligotrophic to a mesotrophic state, characterized by a "Corynocera ambigua/Microtendipes pedellus-type" phase, which has been found in other lakes across Fennoscandia. Taxonomic shifts in the chironomid and cladoceran communities associated with climatic amelioration were identified at ca. 10.6 and $9.17 \mathrm{cal} \mathrm{ka} \mathrm{BP} \mathrm{using} \mathrm{breakpoint} \mathrm{analysis.} \mathrm{Reconstructed} \mathrm{July} \mathrm{temperatures} \mathrm{indicate} \mathrm{climatic} \mathrm{patterns} \mathrm{comparable} \mathrm{to} \mathrm{those}$ seen in eastern Fennoscandia. The warm period between ca. 9.5 and $5.5 \mathrm{cal}$ ka BP (T July $14.5-15^{\circ} \mathrm{C}$ ) was interrupted by a slight cooling between ca. 8.5 and $8.1 \mathrm{cal} \mathrm{ka} \mathrm{BP}$, possibly relating to the 8.2 event, with peak temperature reached at ca. $7.8 \mathrm{cal}$ ka BP. Neoglacial cooling started after ca. $5.5 \mathrm{cal} \mathrm{ka} \mathrm{BP,} \mathrm{the} \mathrm{median} \mathrm{reconstructed} \mathrm{July} \mathrm{temperature} \mathrm{dropped} \mathrm{to} 2-3^{\circ} \mathrm{C}$ cooler than present (mean $\mathrm{T}$ July $13.5^{\circ} \mathrm{C}$ ) before recovering in recent time.
\end{abstract}

Keywords: Northwestern Russia; Karelian Isthmus; Holocene; Chironomids; Cladoceran; LOI; Compositional disorder; Mean July air temperature; Ecosystem change

\section{INTRODUCTION}

The environmental and climatic history of northwestern Fennoscandia has attracted much attention and is relatively well studied (Seppä and Birks, 2001; Seppä and Poska, 2004; Ojala et al., 2008; Stroeven et al., 2016). For this region, numerous studies have reconstructed changes in atmospheric circulation patterns (Shemesh et al., 2001; Rosqvist et al., 2004, 2007; Andersson et al., 2010; Meyer-Jacob et al., 2017) and provided quantitative reconstructions of the

Cite this article: Nazarova, L., Syrykh, L. S., Mayfield, R. J., Frolova, L. A., Ibragimova, A. G., Grekov, I. M., Subetto, D. A. 2020. Palaeoecological and palaeoclimatic conditions on the Karelian Isthmus (northwestern Russia) during the Holocene. Quaternary Research 95, 65-83. https://doi.org/10.1017/qua.2019.88 palaeoclimate from the late glacial period to present, based on pollen and chironomids (Seppä and Birks, 2001; Ojala and Alenius, 2005; Ojala et al., 2005; Luoto et al., 2010; Plikk et al., 2019). However, there is still little information available from the eastern and southeastern regions of Fennoscandia, such as northwestern Russia (but see Solovieva and Jones, 2002; Ilyashuk et al., 2005, 2013), where most extant studies are published in Russian (see review in Subetto [2009] and Subetto et al. [2017]).

Long-term studies of Lake Ladoga and its catchment, situated in northwestern Russia, (Davydova et al., 1996; Subetto et al., 1998; Wohlfarth et al., 2007; Subetto, 2009; Aleksandrovskii et al., 2009) highlight a complex interplay between global and regional-scale hydrological and climatological factors controlling climatic conditions throughout the 
Holocene. Recent progress in qualitative estimation of palaeoclimate in southeast Fennoscandia has come from a comprehensive investigation of the varved sediments from Lake Ladoga, and it includes a complete postglacial pollen record (Savelieva et al., 2019). A further study assessed the Holocene hydrological variability of Lake Ladoga using oxygen isotopes from lacustrine diatom silica (Kostrova et al., 2019). These studies revealed that the lake and its environment underwent significant changes, mainly caused by long- and short-term variations in air temperature and atmospheric precipitation patterns and also strongly influenced by glaciation-deglaciation processes and related glacio-isostatic movements of the Earth's crust (Kostrova et al., 2019). The latter played an especially important role in the hydrological history of the region since the late glacial period.

Several stages of the lake's development have been identified: it was first a gulf of the Baltic Ice Lake basin and then became an independent lacustrine reservoir (Subetto, 2009). This transition included several transgression-regression stages and catastrophic events, including a change in outflow of the Lake Saimaa system in Finland to the southeast, and the formation of major outlet rivers (Subetto, 2009). The complex hydrological history of the region led to strong admixing or elimination of sediment layers in Lake Ladoga itself and in the adjacent postglacial lakes (Subetto, 2009; Kuznetsov, 2014). This strongly limits the possibility of obtaining a continual sedimentary record or quantitative reconstructions of the palaeoclimate for the region.

The probability of continuous sedimentation throughout the Holocene is greater in the lakes from Central Upland of the Karelian Isthmus, located between the Gulf of Finland and Lake Ladoga (between $61^{\circ} 21^{\prime}$ and $59^{\circ} 46^{\prime} \mathrm{N}$ and $27^{\circ} 42^{\prime}$ and $31^{\circ} 08^{\prime} \mathrm{E}$; Fig. 1). Lakes in the lower-lying areas of the Isthmus were repeatedly flooded by the Baltic Sea and Lake Ladoga throughout their development, reducing the likelihood of wellpreserved, complete Holocene records. Therefore, the sediments of the Central Upland lakes of the Karelian Isthmus are particularly important for understanding the evolution of the ecological and climatic conditions in this region. Environmental change in the Karelian Isthmus at the transition from the late Pleistocene to the Holocene has been previously studied (Subetto et al., 1999, 2001, 2002, 2003), but data on Holocene palaeoclimate from this area are extremely scarce (Syrykh et al., 2014, 2015; Nazarova et al., 2018).

Here we present the results of a detailed study of sediments from Lake Medvedevskoe (LM), located on the central upland of the Karelian Isthmus (Fig. 1), using sediment structure, organic matter content, analysis of chironomids (Diptera: Chironomidae) and cladocerans (Crustacea: Branchipoda: Cladocera), and statistical models based on extensive databases of species composition and ecological parameters of the lakes from northern Russia (Nazarova et al., 2008, 2011, 2015). The main aims of our study are: (1) to trace the development of biological communities during the Holocene; and (2) to reconstruct qualitatively and quantitatively the palaeoecological conditions and palaeoclimate, respectively, of the Holocene on the Karelian Isthmus.
Our findings are compared with regional data on the palaeoclimate of Fennoscandia to improve the understanding of Holocene changes in this region.

\section{MATERIAL AND METHODS}

\section{Regional settings and sampling site}

The Karelian Isthmus stretches between the Gulf of Finland, the Baltic Sea, and Lake Ladoga (Fig. 1). It is approximately $45-110 \mathrm{~km}$ wide and is located at the junction of the Baltic Crystaline Shield and the Russian Platform. The Isthmus can be divided into three landscape units: the lowland area in the north characterized by more than 800 lakes, the central highland, which reaches up to $203 \mathrm{~m}$ above sea level (asl), and the Neva Lowland (15-25 m asl) in the south. The Karelian Isthmus was strongly influenced by the Scandinavian Ice Sheet (SIS) during the Weichselian glaciation, and this has determined the heterogeneity of its geological structure and the variety of its landscapes (Subetto, 2009; Stroeven et al., 2016). The last glacial maximum, known as the "Late Valday" glaciation in Russia, has recently been dated to 20.1 cal ka BP in northwestern Russia (Rinterknecht et al., 2018). During this time, the ice margin reached the Valday region $\left(\sim 57^{\circ} \mathrm{N}, 34^{\circ} \mathrm{E}\right)$, ca. $350 \mathrm{~km}$ southeast of the Karelian Isthmus, and extended northwards towards the Barents Sea (Fig. 1A; Svendsen et al., 1999).

The central part of the Karelian Isthmus is thought to have become deglaciated relatively early, prior to $15 \mathrm{cal} \mathrm{ka} \mathrm{BP}$, according to Gromig et al. (2019), although previous estimates were later (14.25-13.3 cal ka BP; Saarnisto and Saarinen, 2001). During deglaciation, the central part of the Karelian Isthmus formed a nunatak that rose above the surface of the glacier and featured small periglacial lakes (Subetto et al., 2002; Subetto, 2009). Hang (1997) and Hang et al. (2000) revised Markov and Krasnov's (1930) varve-diagram correlations to show that the Isthmus became ice-free within a period of ca. 450 varve yr. Today, the region has a cool maritime climate, with a mean January temperature of $-9^{\circ} \mathrm{C}$, mean July temperature (T July) of $+16^{\circ} \mathrm{C}$, and a mean annual temperature of $+3^{\circ} \mathrm{C}$. Precipitation is around $600 \mathrm{~mm} / \mathrm{yr}$ (Subetto, 2009).

The study site, $\mathrm{LM}\left(60^{\circ} 31.850^{\prime} \mathrm{N}, 2^{\circ} 53.950^{\prime} \mathrm{E} ; 102.2 \mathrm{~m}\right.$ asl $)$, is located on the central highland within a hummocky moraine landscape at the outer margin of the Neva marginal formation (Fig. 1). LM was never flooded by larger water bodies following the deglaciation of the Karelian Isthmus.

Earlier studies have shown that the sediments of LM are represented by late-glacial grey sand and clay and Holocene dark-brown organic silt and contain a thin layer of Vedde volcanic ash dated at ca. $12.0 \mathrm{cal} \mathrm{ka} \mathrm{BP}$ (Wastegård et al., 2000; Subetto, et al., 2001). LM is characterized by a slow rate of continuous sedimentation, with allochthonous and aeolian components dominating the sediments (Subetto, 2009). Surrounding vegetation is dominated by Pinus sylvestris, Picea abies, dwarf shrubs, shrubs, lichens, and mosses (Subetto et al., 2002). LM has a surface area of ca. 

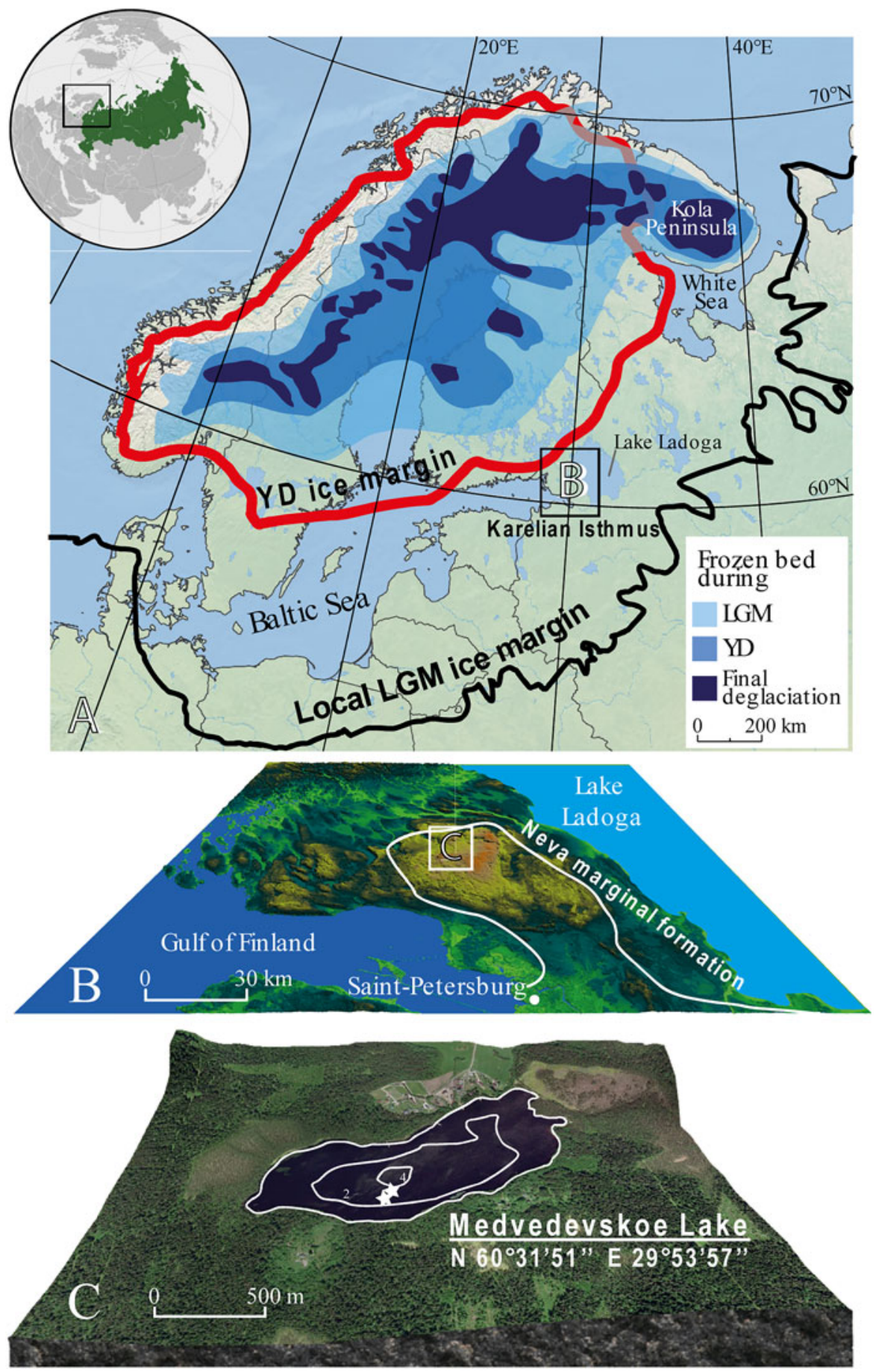

Figure 1. (color online) (A) The shrinkage of the Scandinavian Ice Sheet during deglaciation from its local last glacial maximum (LGM) position (Stroeven et al., 2016); YD = Younger Dryas. (B) Map of the Karelian Isthmus (KI), position of the Neva marginal formation and location of Lake Medvedevskoe on the KI. (C) Lake Medvedevskoe; white stars show coring locations.

$0.46 \mathrm{~km}^{2}$, is $0.39 \mathrm{~km}$ wide and $1.22 \mathrm{~km}$ long, with a maximum depth of $4 \mathrm{~m}$. The lake banks are low, sandy-stony, and loamy. The eastern and western shores merge into wetland. About $20 \%$ of the lake area is overgrown by macrophytes and vegetation extending from the shoreline. Algal blooms are not recorded (Andronikov et al., 2014). The icefree period lasts from April to November (The National Atlas of Russia, 2006). LM is mesotrophic, fed and drained by small creeks, and the water column is unstratified (Subetto et al., 2002).

\section{Fieldwork, geochemistry, and age model}

Two sediment cores, 0.95 and $1.8 \mathrm{~m}$ long, were collected from the ice in spring 2012 using a strengthened Russian corer (chamber length $=1 \mathrm{~m}$, inside diameter $=5 \mathrm{~cm}$ ). Core 1 was 


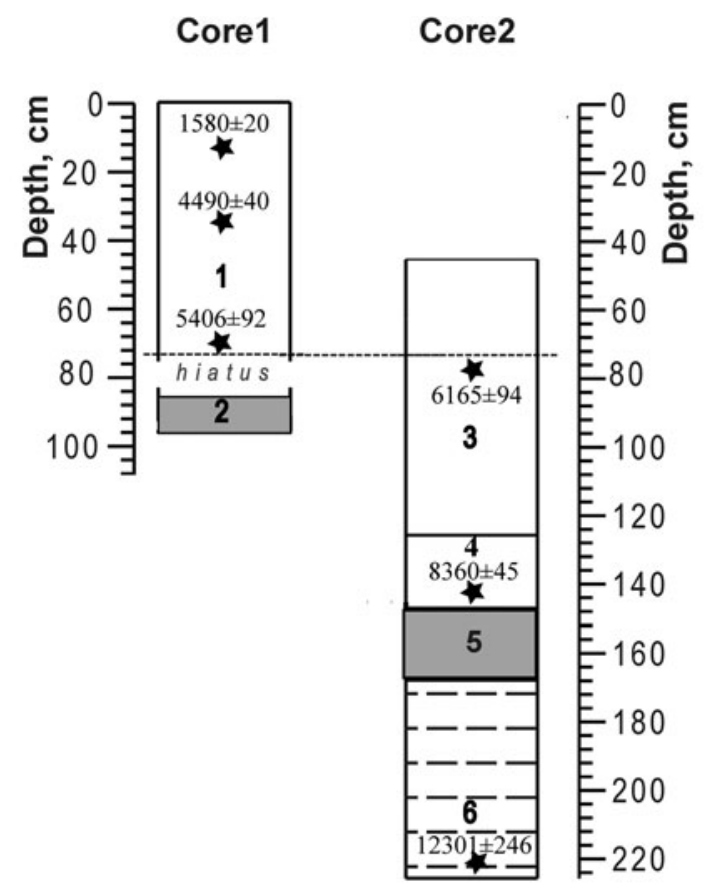

A

\section{1 - 6 Sediment Units}

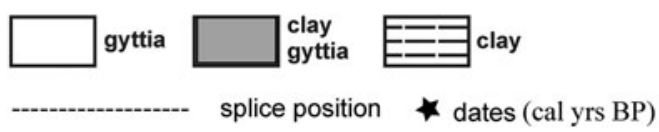

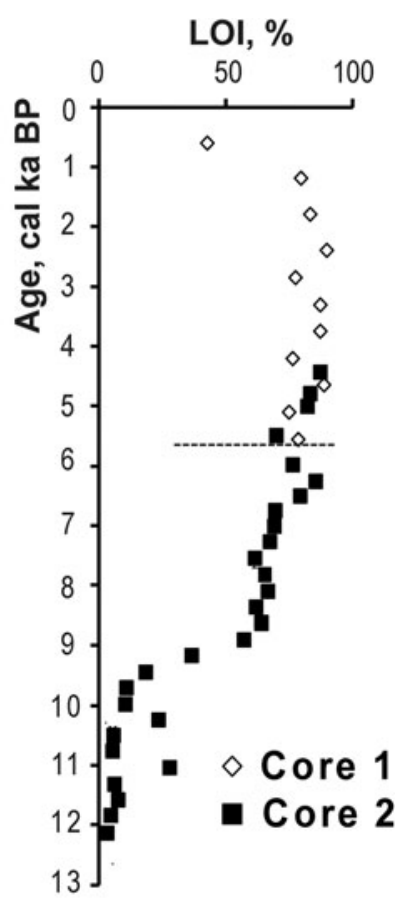

B

Figure 2. Core correlation. (A) Lithostratigraphies of Cores 1 and 2. (B) Results of the loss-of-ignition (LOI) analyses from Cores 1 and 2.

collected from a depth of $2.35 \mathrm{~m}$ and Core 2 was collected from a depth of $4 \mathrm{~m}$. Organic content of the sediments was measured by loss on ignition (LOI, \%) at $550^{\circ} \mathrm{C}$ (Heiri et al., 2001; Ilyashuk and Ilyashuk, 2007). Cores 1 and 2 were correlated to each other according to lithological marker horizons based on the LOI data and accelerator mass spectrometry (AMS) dates (Fig. 2, Table 1).

To construct an age-depth model, samples of bulk sediment were dated via AMS (Fig. 2, Table 1). Bulk material was used due to the lack of available plant material. The

Table 1. Radiocarbon ages and median of calibrated ${ }^{14} \mathrm{C}$ ages in Cores 1 and 2 from Lake Medvedevskoe.

\begin{tabular}{|c|c|c|c|c|c|}
\hline $\begin{array}{l}\text { Lab. } \\
\text { No. } \\
\end{array}$ & Core & $\begin{array}{l}\text { Core } \\
\text { Depth } \\
(\mathrm{cm}) \\
\end{array}$ & $\begin{array}{l}\text { Composite } \\
\text { Core Depth } \\
(\mathrm{cm})\end{array}$ & $\begin{array}{l}{ }^{14} \mathrm{C} \text { age } \\
\text { (yr BP) }\end{array}$ & $\begin{array}{c}\text { Median of } \\
\text { calibrated } \\
\text { ages } \\
\text { (yr BP) }\end{array}$ \\
\hline D50 & 1 & 25 & 25 & $1679 \pm 12$ & $1580 \pm 20$ \\
\hline D39 & 1 & 62 & 62 & $4015 \pm 37$ & $4490 \pm 40$ \\
\hline 55424 & 1 & 72 & 72 & $4676 \pm 68$ & $5406 \pm 92$ \\
\hline 55423 & 1 & 93 & - & $10871 \pm 112$ & $12849 \pm 109$ \\
\hline 55426 & 2 & 16 & 78 & $5368 \pm 71$ & $6165 \pm 94$ \\
\hline D2 & 2 & 68 & 140 & $7546 \pm 53$ & $8360 \pm 45$ \\
\hline 55425 & 2 & 162 & 224 & $10431 \pm 152$ & $12301 \pm 246$ \\
\hline
\end{tabular}

AMS radiocarbon dating of four samples (Lab. No. 55235526; Table 1) was performed in the Laboratory of Ion Beam Physics, Eidgenössische Technische Hochschule (ETH), Zürich. To increase the accuracy of the age model, further three samples were dated in the AMS Laboratory of Taiwan University (D2, D39, D50; Table 1). The uppermost sediment samples of both cores were analysed for ${ }^{210} \mathrm{~Pb}$ activity at the Geochronology Laboratory of St. Petersburg State University in order to obtain an additional time scale and control the upper radiocarbon chronology. ${ }^{210} \mathrm{~Pb}$ was found only in the upper sediment samples of Core 1, which provided evidence for the modern age of the upper part of Core 1. The topmost sediments of Core 2 were not retrieved (Fig. 2), and no ${ }^{210} \mathrm{~Pb}$ was recorded. The lower part of Core 1 , between 74 and $93 \mathrm{~cm}$, had a break in sedimentation (hiatus). Therefore, the upper part of Core 1 was combined with the preserved part of Core 2 to create a composite core for further palaeoecological analysis based on sedimentology and LOI. The lowermost date of Core 1 was omitted from the final age model, as this section of the core was not included in the composite core. The age-depth model (Fig. 3) was calculated with the Bacon 2.2 package (Blaauw and Christen, 2011) for R software ( $\mathrm{R}$ Core Team, 2012). The IntCal13 curve (Reimer et al., 2013), which is default in Bacon 2.2., was used to calibrate the AMS dates. 

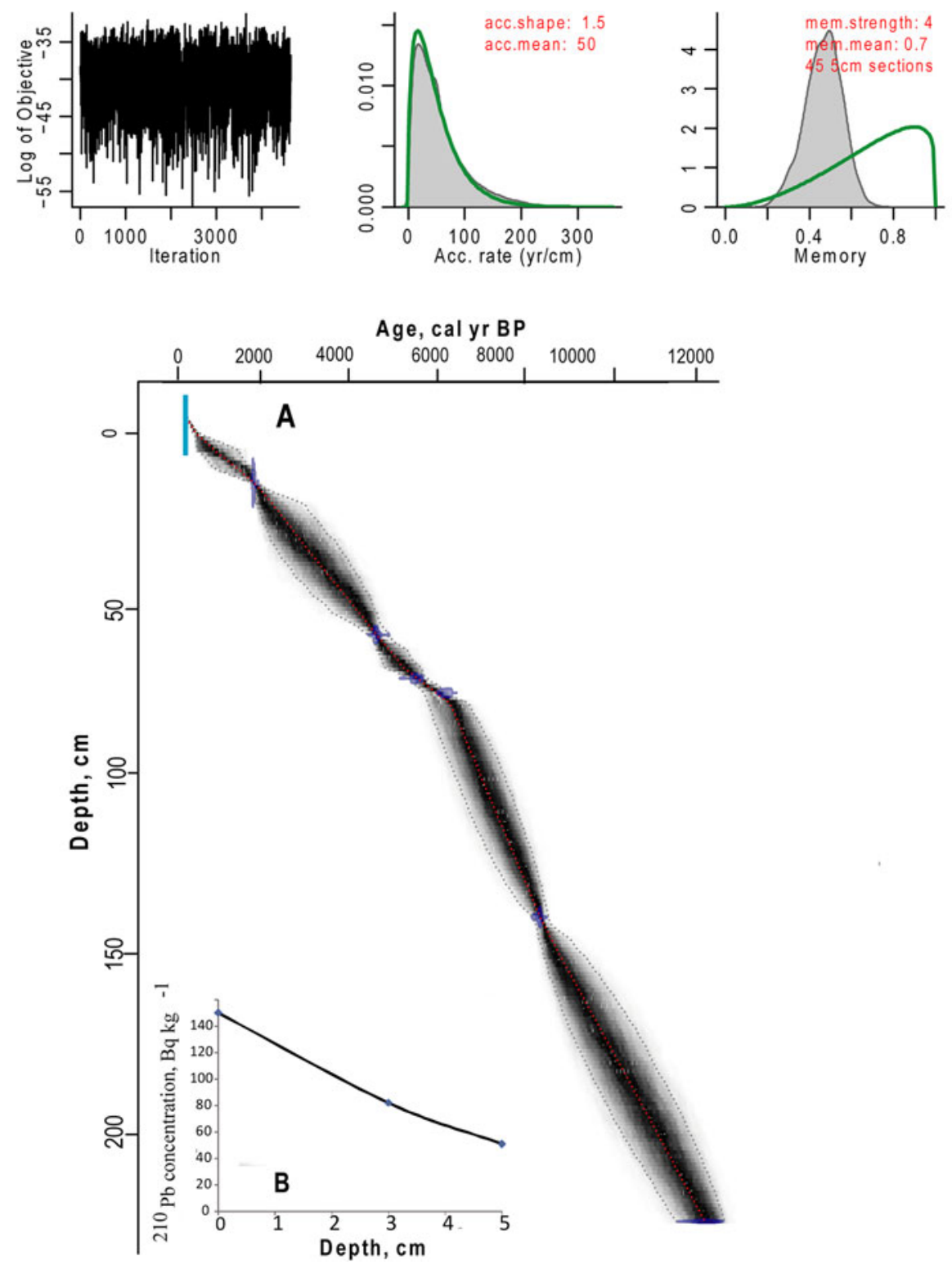

Figure 3. (color online) Age model. (A) Age-depth relationship of the combined core from LM. (B) Results of the ${ }^{210} \mathrm{~Pb}$ analysis of the upper $5 \mathrm{~cm}$ of Core 1 .

\section{Chironomids}

Treatment of sediment samples for chironomid analysis followed standard techniques described in Brooks et al. (2007). Chironomids were identified to the highest taxonomic resolution possible with reference to Wiederholm (1983) and Brooks et al. (2007). To capture the maximum diversity of the chironomid population, 59 to 118 chironomid larval head capsules were extracted from each sample. Several studies have demonstrated that this sample size is adequate for a reliable estimate of inferred temperature (Heiri and Lotter, 2001; Larocque, 2001; Quinlan and Smol, 2001). Information on the ecology of chironomid taxa was taken from Brooks et al. (2007), Moller Pilot (2009), and Nazarova et al. (2008, 2011, 2015, 2017a, 2017b).

\section{Cladocera}

Sediment samples were prepared for Cladocera analysis using the methods described in Korhola and Rautio (2001) and Frolova (2013). The chitinous remains of cladocerans (headshields, shells, postabdomens, postabdomenal claws, and ephippia) were identified with reference to subfossil (Frey, 1959, 1973; Szeroczyńska and Sarmaja-Korjonen, 2007) and modern (Flössner, 2000; Kotov et al., 2010) cladoceran identification keys. Because diverse parts are recorded, the most abundant body part was chosen for each species to represent the number of individuals. Between 88 and 285 individuals per sample were counted from each sub-sample. The percentages for all cladoceran species were calculated from this sum of individuals. 


\section{Numerical methods}

Percentage stratigraphic diagrams were made in the program C2 version 1.7.7 (Juggins, 2007; Fig. 4 and 5). Zonation of stratigraphies was accomplished using the optimal sum-ofsquares partitioning method (Birks and Gordon, 1985) and the program ZONE (Lotter and Juggins, 1991). The number of significant zones was assessed by a broken stick model (Bennett, 1996) using program BSTICK (Birks H.J.B. and Line J.M., unpublished). Species diversity was estimated using Hill's (1973) N2 index, which is commonly used as a measure of "effective" diversity, or a number of equally abundant species needed to obtain the same mean proportional species abundance as that observed in the dataset of interest (where all species may not be equally abundant).

Detrended correspondence analysis (DCA), detrended by segments, was performed on the chironomid and cladoceran data (rare taxa downweighted) to determine the length of the sampled environmental gradients, from which we decided whether unimodal or linear statistical techniques would be most appropriate for the data analysis (Birks, 1995; Palagushkina et al., 2012, 2017). The gradient lengths of species scores were relatively short; the DCA axis 1 gradients were 1.58 standard deviation units for the chironomid data and 2.276 for the cladoceran data. This indicated that numerical methods based on linear response models are the most appropriate to assess the variation structure of the chironomids and cladoceran assemblages (ter Braak, 1995). Principal component analysis (PCA) was used to explore the main pattern of taxonomic variations within the chironomid and cladoceran data throughout the sediment core (ter Braak and Prentice, 1988).

The quantitative air temperature reconstruction was based on calibration data sets of lakes from northern Russia (Nazarova et al., 2008, 2011, 2015, 2017a). T July temperatures were inferred by using a North Russian (NR) chironomidbased temperature inference model (WA-PLS, 2 component; $R^{2}$ boot $=0.81$; RMSEP boot $=1.43^{\circ} \mathrm{C}$ ) based on a modern calibration dataset of 193 lakes and 162 taxa from northern Russia $\left(61-75^{\circ} \mathrm{N}, 50-140^{\circ} \mathrm{E}\right.$, $\mathrm{T}$ July range $=1.8$ to $18.8^{\circ} \mathrm{C}$; Nazarova et al., 2015). T July for the lakes in the calibration dataset was derived from a climatic dataset compiled by New et al. (2002). The T July NR model has been previously applied for palaeoclimatic inferences in Siberia and European northern Russia and demonstrated high reliability of reconstructed parameters (Kienast et al., 2011; Solovieva et al., 2015; Diekmann et al., 2016).

Chironomid-based reconstructions were performed in C2 version 1.7.7 (Juggins, 2007). The species data were squareroot transformed to stabilise species variance. To assess the reliability of the chironomid-inferred $\mathrm{T}$ July reconstruction, we calculated the percentage abundances of the fossil chironomids that are rare or absent in the modern calibration data set. A taxon is considered to be rare in the modern data when it has a Hill's N2 (Hill, 1973) value below five. The temperature optima of the taxa that are rare in the modern dataset are likely to be poorly estimated (Brooks and Birks, 2001).
A goodness-of-fit statistic (GoF), derived from a canonical correspondence analysis (CCA) of the modern calibration data and down-core passive samples with T July as the sole constraining variable, was used to assess the fit of the analysed down-core assemblages to the reconstructed $\mathrm{T}$ July (Birks et al., 1990; Birks, 1995, 1998). This method shows how unusual the fossil assemblages are in respect to the composition of the training set samples along the temperature gradient. Fossil samples with a residual distance to the first CCA axis larger than the 90th and 95th percentile of the residual distances of all the modern samples were identified as samples with a "poor fit" and a "very poor fit," respectively, with the reconstructed T July (Birks et al., 1990).

PCA and CCA were performed using CANOCO 4.5 (ter Braak and Šmilauer, 2002). Chironomid percentage data were square-root transformed and rare taxa were downweighted. In the evaluation of GoF, the CCA scaling focused on inter-sample distances with Hill's N2 scaling selected to optimise inter-sample relationships (Velle et al., 2005).

DCA was run on the square-root transformed LM temporal chironomid and cladoceran sequences, using the vegan package in R (Oksanen et al., 2017), and the DCA scores were analysed for breakpoints, using the strucchange package in $\mathrm{R}$ (Zeileis et al., 2002, 2003). The DCA axis 1 scores for the composite core were compared to DCA axis 1 scores calculated independently for Core 1 and 2, for both the chironomid and cladoceran data, in order to additionally test the acceptability of merging the taxa datasets from Core 1 and 2 into a composite assemblage.

Community composition change was explored using species richness, species diversity (Hill's N2) and compositional disorder ( ${ }^{\circ}$ disorder) analyses for the temporal chironomid and cladoceran assemblages, following Doncaster et al. (2016). Compositional disorder allows the species assemblages to be analysed further by investigating how the community composition is changing, and whether this is in a linear, predicable manner, or an unstructured, disordered manner, which may be indicative of an approaching critical transition (Doncaster et al., 2016). Compositional disorder is measured on a continuous scale similar to temperature, with $0^{\circ}$ indicating a highly ordered, completely nested community, wherein the species assemblage is a subset of the previous one and is therefore predictable. A highly disordered species composition has a value of $100^{\circ}$, indicating a completely unnested community where the species composition is unpredictable due to a lack of common species (Rodriguez-Girones and Santamaria, 2006; Doncaster et al., 2016). ${ }^{\circ}$ Disorder was calculated using a 10-point subset, where the calculation for one data point included the following nine data points, hence ${ }^{\circ}$ disorder values are not available for the lower 9 data points.

\section{RESULTS}

\section{Lithology, geochemistry, and age model}

In the lithological structure of Core 1, two sediment units can be distinguished: a dark-brown organic $83-\mathrm{cm}$-thick gyttja 


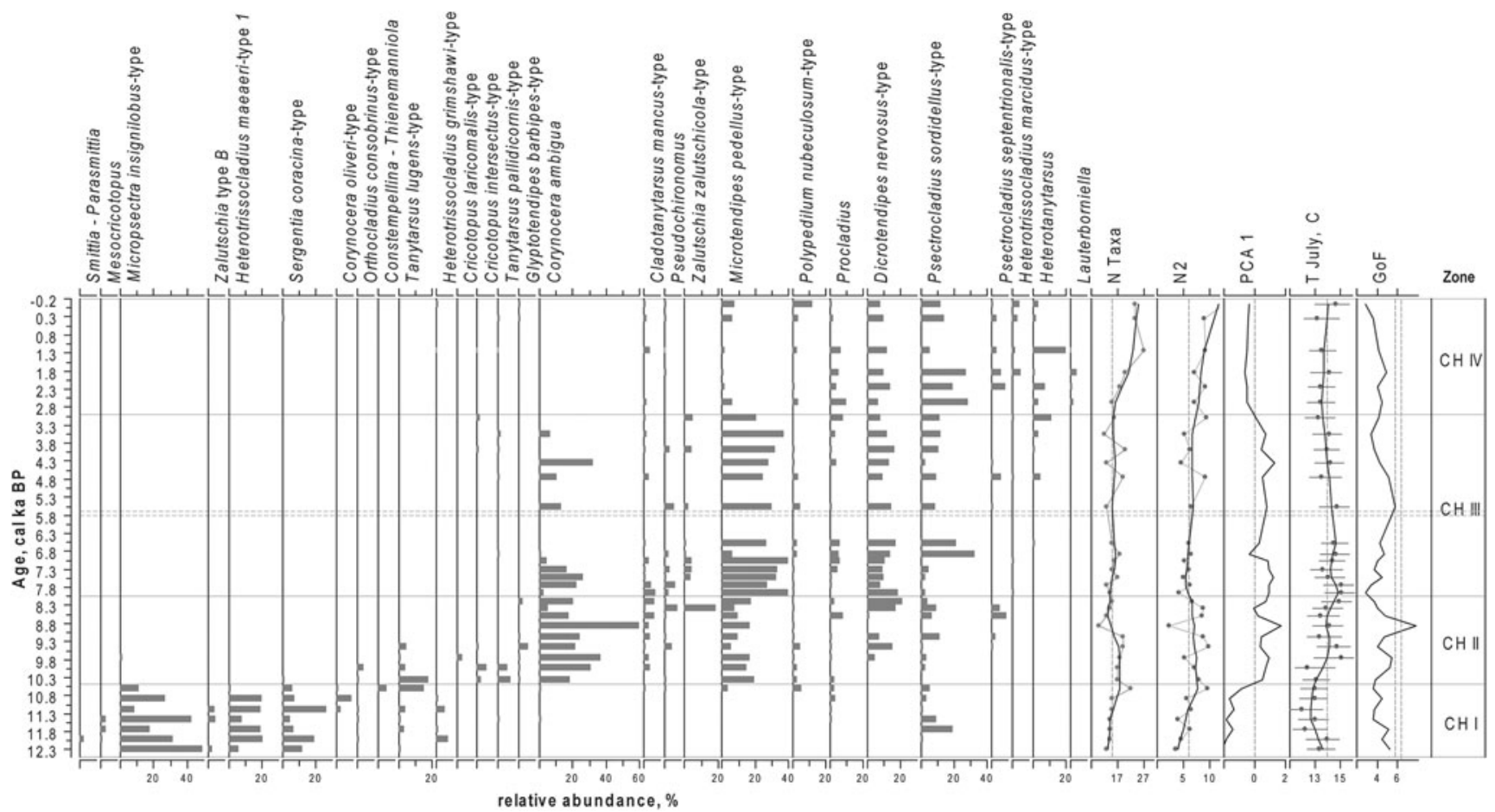

Figure 4. Relative proportions of the most abundant chironomid taxa in the sediments of Lake Medvedevskoe (LM), chironomid-inferred mean July air temperature (T July), PCA axes 1 scores for chironomid data, N2 diversity, number of chironomid taxa (N Taxa), and results of goodness-of-fit (GoF) tests for reconstructed T July, with 90th and 95th percentile of the residual distances of all the modern samples that are identified as samples with a "poor fit" and a "very poor fit" with the reconstructed T July, respectively (dashed lines). For taxon abundances, black lines represent a LOESS 0.2 smoothing of the data. For N2 and, N Taxa grey lines with dots represent the data and black lines represent a LOESS 0.2 smoothing of the data.

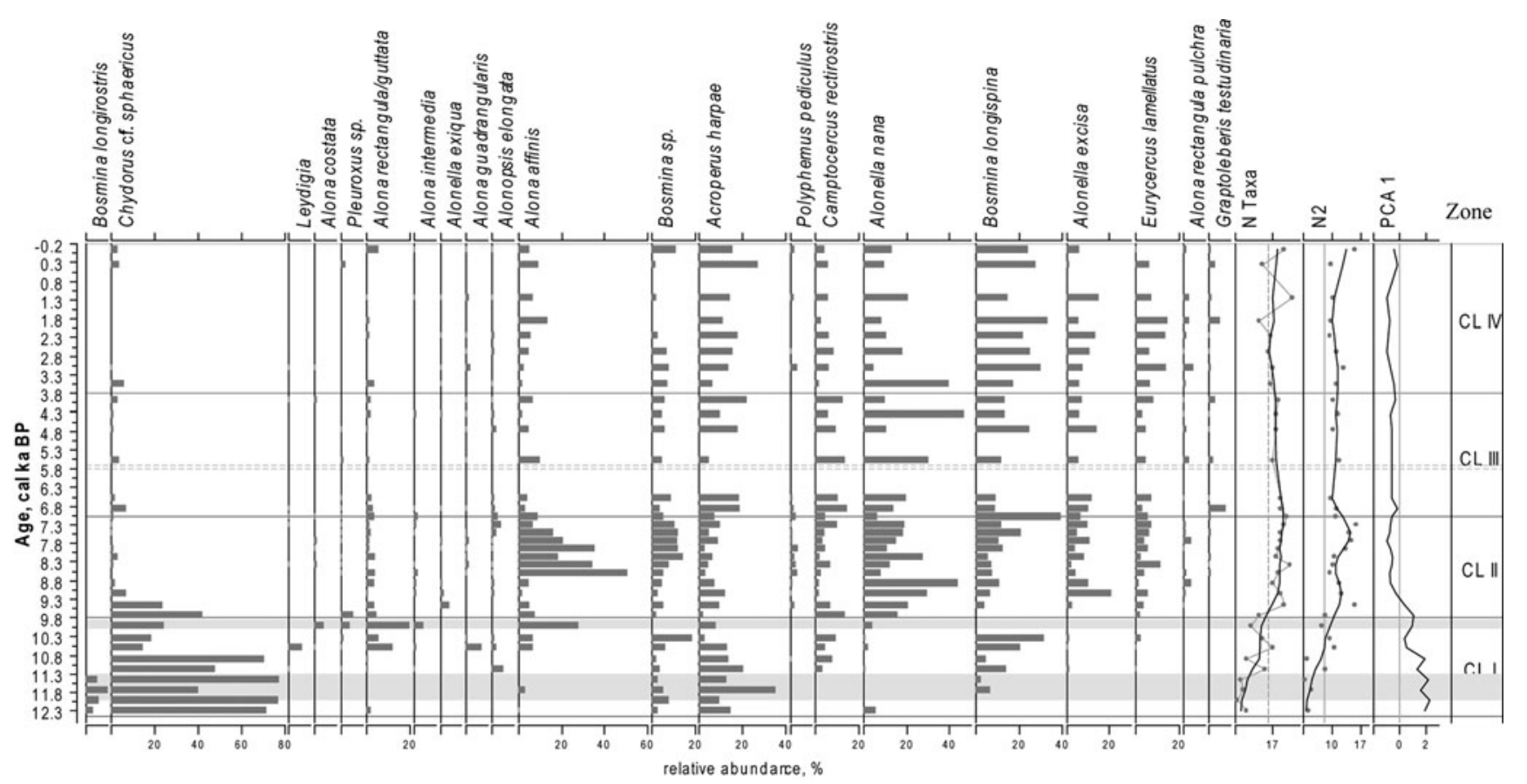

Figure 5. Relative proportions of the most abundant Cladocera taxa in the sediments of LM, PCA axes 1 scores for Cladocera data, N2 diversity, number of Cladocera taxa (N Taxa) of the Cladocera communities. For taxa abundances black lines represent a LOESS 0.2 smoothing of the data. For N2 and N Taxa grey lines with dots represent the data, black lines represent a LOESS 0.2 smoothing of the data. Grey areas represent layers with low concentration of cladoceran remains. 
(unit 1; Fig. 2A) and a 12-cm-thick, greenish-grey, layered, silty clay gyttja (unit 2). The lithological structure of Core 2 was similar, with the upper $108 \mathrm{~cm}$ of the core consisting of organic gyttja (units 3 and 4), of which the lower $20 \mathrm{~cm}$ had weak lamination (unit 4). Unit 5 of Core $2(23 \mathrm{~cm}$ thick) was similar to unit 2 of Core 1 and was also represented by greenish-grey, silty clay gyttja. The lowermost unit 6 consisted of dark-grey, dense, silty clay with admixed sand.

Results of the LOI analysis demonstrated complimentary trends across the two cores. The LOI values gradually increased from $4-6 \%$ at the lowermost parts of Core 2, with up to $87 \%$ at the central, overlapping sections and the upper section of Core 1 (Fig. 2B).

The ${ }^{14} \mathrm{C}$ results from both Core 1 and 2 show that the dates are in chronological order (Fig. 2, Table 1). We spliced the upper $72 \mathrm{~cm}$ of Core 1 at $28 \mathrm{~cm}$ core depth of the remaining part of Core 2, where both records had identical LOI values, the closest obtained ${ }^{14} \mathrm{C}$ dates and the modelled ages based on AMS dates showed similar ages (Fig. 2 and 3, Table 2). Further support for the chosen splicing approach and the resulting age model was obtained from the DCA analysis of the biological assemblages of both Core 1 and 2 (SOM 1; Fig. 1 and 2). A large degree of overlap in the DCA scores for axes 1 and 2 for Core 1 and 2 (SOM 1; Fig. 1 and 2) suggests broadly similar taxonomic compositions within the two cores at the chosen splicing position. As LM has a simple bathymetry, merging the datasets to create a composite core is not unreasonable. The resulting composite core was 224 $\mathrm{cm}$ long and covered a time interval from ca. $12.3 \mathrm{cal} \mathrm{ka}$ BP to the present-day (Fig. 3, Table 1).

\section{Chironomids}

In total, we identified 82 chironomid taxa. The down-core changes in the chironomid assemblages led to the identification of four statistically significant zones (CH I-IV; Fig. 4).

Table 2. Lithostratigraphic description of the sediment cores from Lake Medvedevskoe.

\begin{tabular}{lrl}
\hline \hline Unit & $\begin{array}{c}\text { Depth } \\
(\mathrm{cm})\end{array}$ & \multicolumn{1}{c}{ Characteristic } \\
\hline $\begin{array}{l}\text { Core } 1 \\
1\end{array}$ & $0-83$ & $\begin{array}{c}\text { Dark-brown, organic gyttja with a clear lower } \\
\text { boundary. }\end{array}$ \\
2 & $83-95$ & $\begin{array}{l}\text { Greenish-gray, silty clay gyttja with brownish } \\
\text { interlayers. }\end{array}$ \\
$\begin{array}{l}\text { Core } 2 \\
3\end{array}$ & $0-88$ & $\begin{array}{l}\text { Dark-brown, organic gyttja with detritus } \\
\text { inclusions. }\end{array}$ \\
4 & $88-108$ & $\begin{array}{l}\text { Dark-brown, organic gyttja with weak } \\
\text { lamination. The upper boundary is not clear. }\end{array}$ \\
5 & $108-131$ & $\begin{array}{c}\text { Greenish-grey, silty clay gyttja with a sharp lower } \\
\text { boundary. }\end{array}$ \\
6 & $131-180$ & \begin{tabular}{l} 
Dark-grey, dense, silty clay with admixed sand. \\
\hline \hline
\end{tabular}
\end{tabular}

\section{CH I (ca. 12.3-10.5 cal ka BP)}

Species richness is low. The N2 diversity varies from 3.5 to 6.5 and increases to 9.0 at the top of this zone (ca. $10.6 \mathrm{cal}$ ka BP). Chironomid faunas are dominated by coldstenothermic taxa characteristic of oligotrophic conditions, such as Micropsectra insignilobus-type and Sergentia coracina-type, and by Heterotrissocladius maeaeri-type 1 , which is indicative of moderate temperature conditions. In this zone, a number of less abundant, cold oligotrophic indicators occur: Corynocera oliveri-type, Zalutschia type B, Mesocricotopus, and Heterotrissocladius grimshawi-type. The abundance of Tanytarsus lugens-type, a coldstenothermic, profundal taxon, increases towards the top of the zone, indicating a possible lake deepening at this time. In this zone, a combination of acidophilic (Heterotrissocladius, S. coracina-type, Mesocricotopus, and Psectrocladius sordidellus-type) and acidophobic ( $M$. insignilobus-type) taxa alternate in dominance.

\section{CH II (ca. 10.5-8.0 cal ka BP)}

Throughout this zone, $\mathrm{N} 2$ diversity remains around 8.1, with the highest taxonomic richness between ca. 9.5 and $8.3 \mathrm{cal} \mathrm{ka}$ BP. A strong decline in N2 values and species richness occurs at ca. 8.9 cal ka BP, when the dominant taxon in this zone, Corynocera ambigua, constitutes $64 \%$ of the chironomid fauna. Sublittoral/littoral taxa characteristic of warmer conditions and associated with macrophytes prevail: C. ambigua, Microtendipes pedellus-type, Dicrotendipes nervosus-type, Zalutschia zalutschicola-type, and Cladotanytarsus mancus-type.

\section{CH III (ca. 8.0-3.0 cal ka BP)}

$\mathrm{N} 2$ diversity is slightly lower in this zone (median 6.1). $C$. ambigua gradually declines and the fauna is dominated by $M$. pedellus-type, with high abundancies of meso- to eutrophic taxa: D. nervosus-type, P. sordidellus-type, and Procladius.

\section{CH IV (ca. 2.9 cal ka BP-present time)}

This period is characterized by the highest taxonomic richness and diversity (N2 median of 9.3) and a strong taxonomic shift: C. ambigua disappears from the fauna and M. pedellustype declines. The chironomid fauna is dominated by D. nervosus-type, P. sordidellus-type, Procladius, and several other eutrophic and acidophilic taxa, including Heterotanytarsus, Psectrocladius septentrionalis-type, Heterotrissocladius macridus-type, and Lauterborniella.

\section{Cladocera}

Throughout the LM core, a total of 38 cladoceran taxa were found, belonging to seven families: Bosminidae, Holopedidae, Chydoridae, Daphnidae, Polyphemidae, Macrotricidae, and Sididae. Both pelagic and littoral taxa are well 
represented in the lake and the cladoceran communities are dominated by Chydoridae (75.28\%) and Bosminidae (22.67\%) species. The LM cladoceran stratigraphic diagram (Fig. 5) is subdivided into four statistically significant stratigraphic zones (CL I-IV; Fig. 5).

\section{I (ca. 12.3-9.8 cal ka BP)}

The cladoceran communities in this zone are characterized by the lowest $\mathrm{N} 2$ indices in the record and dominance of typical arctic Cladocera species (Acroperus harpae, Chydorus cf. sphaericus, and Bosmina (Eubosmina) longispina). Between ca. 12.0 and 11.3 and around ca. 9.9 cal ka BP, only a few cladoceran remains were found. This part of the core is marked in grey in Figure 5. The average value of N2 diversity in CL I is 5.5. This period is characterized by a strong dominance of cosmopolitan Chydorus cf. sphaericus (Flössner, 2000; Frolova et al., 2013, 2014, 2017a), which decreases in abundance towards the upper levels of the zone. The subdominant species Arcoperus harpae and Chydorus cf. sphaericus are typical and often dominant species in modern northernmost arctic lakes and ponds (Frolova, L., personal communication, 2019). The second part of the period is marked by increases in oligosaprobic, planktonic taxa that are typical of cold-water Bosmina (Eubosmina) longispina (Frolova, 2016; Frolova et al., 2017b).

\section{II (ca. 9.8-7.1 cal ka BP)}

The mean value of N2 increases to 14.6. There are significant changes in the composition of subfossil cladoceran communities connected with an increase in species indicative of changing environmental and climatic conditions. $C$. cf. sphaericus (Fig. 5) declines and nearly disappears from the record after 9.1 cal ka BP. Remains of the predatory Polyphemus pediculus are common during this period. The abundance of $B$. (E.) longispina slightly decreases at the bottom of the zone and increases again towards the top.

\section{III (ca. 7.1-3.8 cal ka BP)}

The average value of $\mathrm{N} 2$ diversity declines to 9.3. There is a sharp decrease in the number of relatively large phytophilic $A$. affinis that dominated CL II as well as a simultaneous increase in A. nana, a small vegetation dweller. Proportions of $A$. harpae, Camptocercus rectirostris, and Graptoleberis testudinaria increase compared with the previous zone.

\section{IV (ca. 3.8 cal ka BP-present time)}

The average value of $\mathrm{N} 2$ diversity index decreases further to 8.6. The zone is characterized by a decline in A. nana. At the same time, the pelagic $B$. $(E)$. longispina became dominant again. There was also an increase in abundances of Eurycercus sp. and A. affinis.

\section{Community composition}

The trends seen in the species richness, Hill's N2 diversity and DCA axis 1 scores are similar for the chironomid and cladoceran communities: DCA axis 1 scores show a shift in community composition during the early Holocene development of the ecological system in LM (Fig. 6). Breakpoint analyses identified statistical breaks in the DCA axis 1 scores at $3.12,9.17$, and $10.60 \mathrm{cal} \mathrm{ka} \mathrm{BP}$ in the chironomid community, and at 9.17 and 10.60 cal ka BP in the cladoceran community, suggesting significant shifts in the species present at these intervals.

The chironomid community shows a high level of ${ }^{\circ}$ disorder $\left(44-46^{\circ}\right)$ during the early Holocene, while the Cladocera community appears more organised at this point, with ${ }^{\circ}$ disorder values of $15-23^{\circ}$. Between ca. 6.7 and 2.9 cal ka BP, approximately corresponding to the middle Holocene, the chironomid and cladoceran communities display a long period of stable community conditions $\left({ }^{\circ}\right.$ disorder values between ca. $30-37^{\circ}$ ). During the late Holocene (ca. 2.9 cal $\mathrm{ka} \mathrm{BP}$ to present), ${ }^{\circ}$ disorder declines to values of $28-23^{\circ}$.
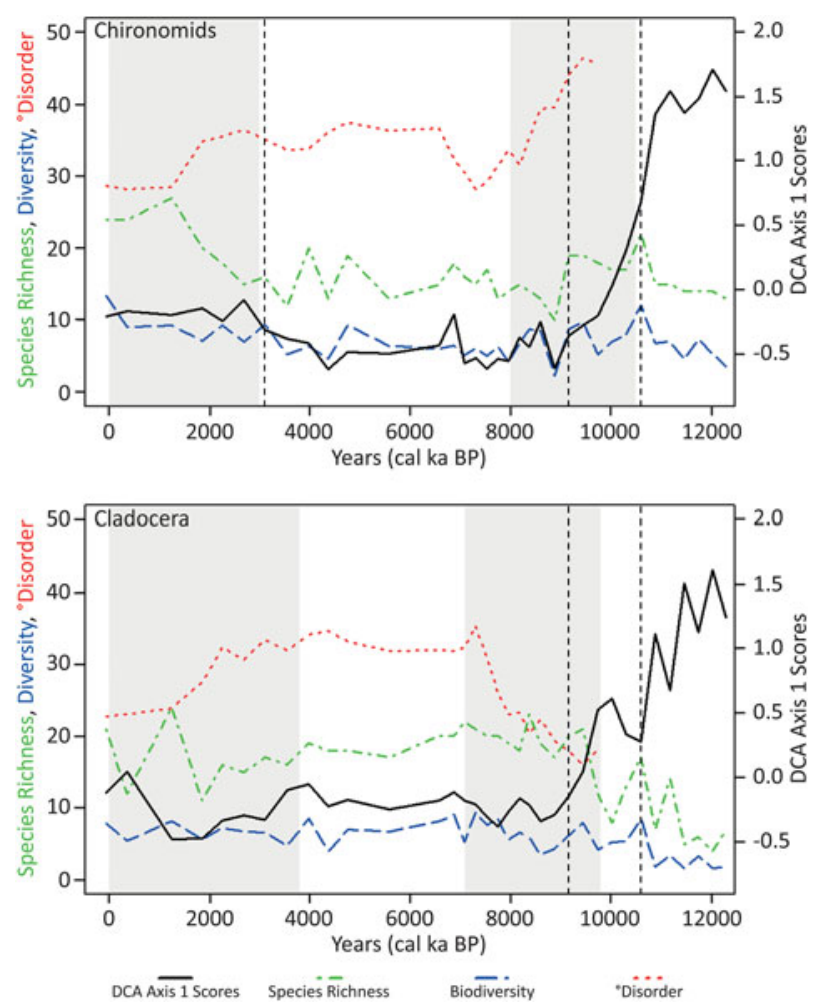

Figure 6. Species richness (green, dot-dashed line), Hill's N2 diversity (blue, dashed line), compositional disorder (red, dotted line) and DCA axis 1 scores (black, solid line), plotted against time for the chironomid and Cladocera species communities. The vertical dotted lines represent statistically calculated breakpoints in the DCA axis 1 scores at 3.12, 9.17, and $10.60 \mathrm{cal} \mathrm{ka} \mathrm{BP}$ in the chironomid community, and at 9.17 and $10.60 \mathrm{cal} \mathrm{ka} \mathrm{BP}$ in the Cladocera community. Stratigraphic zones identified within the chironomids and Cladocera zones are displayed in pale blue-grey. (For interpretation of the references to color in this figure legend, the reader is referred to the web version of this article.) 


\section{Reconstruction of the mean July air temperature (T July)}

Reconstructed T July fluctuates by approximately $3^{\circ} \mathrm{C}$ over the last ca. $12.3 \mathrm{ka}$ (Fig. 4). The main variation shows temperatures being lowest (median T July $12.9^{\circ} \mathrm{C}$ ) in the period between ca. 11.7 and $10.3 \mathrm{cal} \mathrm{ka} \mathrm{BP}$ and highest between ca. 9.7 and 5.5 cal ka BP (for this interval, median $\mathrm{T}$ July = $14.5^{\circ} \mathrm{C}$, $\max \mathrm{T}$ July $=15.1^{\circ} \mathrm{C}$ ). Temperatures fluctuate within the generally warm early Holocene, with lower values ca. 8.5-8.1 and ca. 7.3-6.8 cal ka BP. From ca. 5.5 to 0.1 cal ka BP there was a gradual cooling of temperature (median T July $=13.5^{\circ} \mathrm{C}$ ). $\mathrm{T}$ July in the modern sample is reconstructed as $14.8^{\circ} \mathrm{C}$, which is similar to the modern $\mathrm{T}$ July $\left(16^{\circ} \mathrm{C}\right)$, taking into account the RMSEP of the applied model $\left(1.43^{\circ} \mathrm{C}\right)$.

All dominant taxa in the fossil record are well represented $(\mathrm{N} 2>5)$ and all 82 identified chironomid taxa were represented in the modern training sets. Eight of the 82 taxa had a Hill's N $2<5$ and therefore are defined as not well represented in the training sets: Einfeldia pagana-type, Harnischia, Hydrobaenus johannseni-type, Paracladopelma, and Stenochironomus Xenochironomus. These taxa appear in the record once each. Lauterborniella appears in three samples in $\mathrm{CH}$ IV at abundances of $0.8-1.6 \%$ and once at an abundance of $3.7 \%$ at ca. 1.8 cal ka BP. All these seven taxa are rare in the record, appear at low abundances, and therefore do not influence the reconstruction. GoF statistics for $\mathrm{T}$ July reconstruction reveal that only one sample has a "poor" fit with temperature (Fig. 4). In this sample (ca. 8.9 cal ka BP), the chironomid fauna is strongly dominated by C. ambigua (64\%). The rest of the samples show a "good fit" with temperature (see Materials and Methods). The high representation of the taxa in the training set, together with mostly good GoF statistics results, indicates that the temperature reconstruction from the LM records is reliable.

\section{DISCUSSION}

The analysis of fossilized biological remains from the sediments of LM, at the southeastern edge of Fennoscandia, gives an insight into changes in chironomids and cladoceran communities since the late Pleistocene. This provides an opportunity to infer the paleoclimate and lake-basin development, and, by comparison our data with information available from other parts of Fennoscandia, our results can be placed into a broader geographical context.

\section{Faunal changes}

In both the chironomid and cladoceran communities, we observed several phases with clearly expressed dominant species. Taxonomic richness of biological communities was low at the base of the core and generally increased towards the sediment surface, along with organic content (LOI). In the Cladocera communities, the most prominent taxonomic shift coincided with an increase in organic matter concentration between ca. 10.6 and 9.1 cal ka BP. At this time, cold-water littoral (Ch. cf. sphaericus and A. harpae), tolerant to oxygen variations (Ch. cf. sphaericus) and planktonic cold-water oligosaprobic taxa $(B .[E$.] longispina) were replaced by fauna typically associated with submerged vegetation (Alona, Alonella, and Eurycercus sp.). In the chironomid communities, cold stenotherms, such as $M$. insignilobus-type, H. maeaeri-type, and S. coracina-type, dominated the record before $10.5 \mathrm{cal} \mathrm{ka} \mathrm{BP}$, indicating cold climatic conditions and an input of cold thawing waters from surrounding area.

Between ca. 10.4 and 7.3 cal ka BP, the chironomid $C$. ambigua was dominant, with a high abundance of M. pedellus-type. Between ca. 7.3 and 3.1 cal ka BP, $M$. pedellus-type dominated with $C$. ambigua present (Fig. 4). M. pedellus-type is a known indicator of oligomesotrophic lakes (Brodersen et al., 1998), can tolerate slight acidification (Moller Pillot, 2009), and is rarely found under eutrophic conditions (Langdon et al., 2006). C. ambigua proliferated during the Late Glacial in northern Europe at low temperatures in lakes with silty and largely inorganic sediments, abundant oxygen, and probably extensive charophyte beds in transparent, carbonate-rich waters (Brodersen and Lindegaard, 1999). With climatic amelioration, extensive erosion, and redeposition of lake sediments (Digerfeldt, 1986; Nazarova et al., 2013a) and an increase in nutrient availability could have led to an outward spread of aquatic macrophytes (Digerfeldt, 1986) and a change from a "Chara" to "Potamogeton lake" (Forsberg, 1965); this might have contributed to the reduction in $C$. ambigua populations in northern Europe and in LM.

Similar C. ambiqua/M. pedellus-type stages (CH II; Fig. 4) have been found in several sites around the region, where high abundancies of these two taxa coincided with periods of increasing organic matter content in sediments, representing a transition from oligotrophic to oligomesotrophic or mesotrophic states during the early Holocene. In southern Finland, this stage occurred earlier, from ca. 11.5 to 10.5 cal ka BP (Luoto et al., 2010), and C. ambigua remained present until 7.5 cal ka BP. In northeastern Fennoscandia, on the Kola Peninsula and on the Karelian Isthmus (LM), the C. ambiqua/M. pedellus-type stage was delayed. In the north of the Kola Peninsula it lasted until ca. 9.6 cal ka BP (Ilyashuk et al., 2013) and in the south of the Kola Peninsula it appeared simultaneously with the Karelian Isthmus (LM): from ca. 10.0 to 8.0 cal ka BP (Ilyashuk et al., 2005).

Biological communities in the last ca. $3 \mathrm{ka}$ became progressively diverse and both cladoceran and chironomid faunas included mostly phytophilic and acid-tolerant taxa, presumably in response to further changes, including lake paludification.

Shifts in taxonomic composition are mirrored by the results of species richness and diversity analyses; breakpoints identified in the DCA axis 1 scores coincide with an increase in species richness and diversity for both chironomids and Cladocera (Fig. 6). The breakpoints do not directly match the boundaries between the $\mathrm{CH}$ and $\mathrm{CL}$ zones but indicate 
considerable changes in the composition of biological communities around these boundaries.

The time series plot of compositional disorder ( ${ }^{\circ}$ disorder), species richness and species diversity (Fig. 6) shows gradual changes in the species community composition over time. The rise in species richness and diversity are parallel, signifying an increase in the evenness of the distribution of species abundance in connection with the rising number of species. While species richness and diversity provide information about the number of species present and their abundance, ${ }^{\circ}$ disorder can help infer information about the orderliness of species loss or gain. Higher ${ }^{\circ}$ disorder values indicate more disorder in the species turnover. On a broad time scale, increases in species richness and diversity correlate with lower ${ }^{\circ}$ disorder values, showing, for a given time period, the community composition had many species in common with the previous time slice and was therefore developing in a predictable manner.

While species richness and diversity rise gradually over time in the chironomid and Cladocera assemblages as expected in a developing ecosystem, the ${ }^{\circ}$ disorder scores suggest opposing results for the Cladocera and chironomid communities during the early Holocene. The high ${ }^{\circ}$ disorder values in the chironomid community suggest that there was a large turnover of species and few common species between samples, in keeping with an ecosystem reacting to a developing environment following deglaciation (Subetto et al., 2002). In these early stages (12.0 to $9.0 \mathrm{cal} \mathrm{ka} \mathrm{BP}$ ), species richness is relatively low, between 13-22 species. The chironomid assemblage diagram also shows a number of species with a fluctuating presence during this period (Fig. 4). In contrast, the early-stage cladoceran communities have lower values of ${ }^{\circ}$ disorder, despite species richness showing greater variation (4-21 species; Fig. 5 and 6). This suggests that there were fewer species lost and a more ordered community development.

The opposing ${ }^{\circ}$ disorder values seen in the chironomid and Cladocera assemblages can be explained by the variables that influence the organisms' presence. Chironomid species react to changes in July air temperature (Brooks et al., 2007; Nazarova et al., 2015); these were often more developed in the early Holocene, when the climate was undergoing widespread change. Cladocera are more indicative of water variables, such as phosphorus (Lotter et. al., 1998), lake depth (Korhola, 1999), and water temperature (Frolova et al., 2014). The high ${ }^{\circ}$ disorder values in the chironomid data could indicate that the surrounding terrestrial environment was still highly variable in the early Holocene. In contrast, the aquatic environment of LM may have undergone greater development during the middle Holocene period, where Cladocera ${ }^{\circ}$ disorder values were highest.

Species richness and biodiversity have been highest in the most recent period, ca. $2.9 \mathrm{cal}$ ka BP to present, when ${ }^{\circ}$ disorder is also at its lowest. The different time slices have more species in common, suggesting less turnover of species in association with a more stable wider environmental system in recent time.

\section{Palaeoclimate and lake-basin development}

Trends in the organic matter content of the sediment and biological community composition provide a reconstruction of climate and lake catchment development from the Pleistocene/Holocene boundary to modern time. Qualitative patterns of change, together with the chironomid-based $\mathrm{T}$ July reconstruction, demonstrate that the lake ecosystem was highly responsive to large-scale climatic forcing during the Holocene.

\section{Late Pleistocene / Holocene transition (12.3-10 cal ka $B P$ )}

The lower part of the core (Fig. 2-6) clearly represents the initial stage of the formation of LM during the beginning of deglaciation. Sediments from this time interval are dark-grey, dense, silty clay with admixed sand and very low organic matter content. Biological communities were poor, with low taxon richness and diversity and cold-stenothermic oligotrophic taxa dominating. During this time, Chydorus cf. sphaericus, a pioneering, eurytopic, highly adaptive species, was abundant. This is ecologically flexible species that can withstand varying levels of dissolved oxygen. It is a nearshore (littoral) organism with limited swimming abilities, most commonly found clinging to various filamentous algae with its modified limbs (Fryer, 1968). Chydorus cf. sphaericus is generally found in lakes on or near the bottom sediments. Another abundant species, Acroperus harpae, is a common inhabitant of the littoral areas of lakes and other small water bodies. It is most frequently found in association with vegetation, although occasionally it can be found on bare rocky shores or sand (Fryer, 1968). Paleolimnological studies show that A. harpae is an indicator of cold temperatures (Kattel and Sirocko, 2011). During this time interval, highest abundances of the acidophobic M. insignilobus-type were accompanied by declines in acidophilic taxa, and vice versa (Fig. 4). This probably reflects fluctuations in water depth and variation in the development of the macrophytes in the littoral zones.

The dominance of a cold-stenothermic fauna with the presence of semiaquatic chironomid taxa (Smittia-Parasmittia), which can tolerate variations in oxygen saturation, and alternating dominance of acidophilic and acidophobic taxa further indicate the instability of lacustrine conditions and, probably, erosion of the lake shore during the initial stages of lake formation. Variations in lake depth and water chemistry might also have resulted from the amount and intensity of thawed water supply; this probably caused waterlogging of the shoreline zone of the lake and affected the intensity of humic acid input from surface runoff in the drainage area (Subetto et al., 2003; Wohlfarth et al., 2007).

Mean July temperatures at this time, as inferred from the chironomid record of LM (Fig. 4) were $3-4^{\circ} \mathrm{C}$ below modern level. Earlier studies have shown that before ca. $12.65 \mathrm{cal} \mathrm{ka}$ BP, the climate on the Karelian Isthmus was arctic, cold, and dry (Subetto et al., 2003). In summer, the lake received water 
from the nearby glacier and melting blocks of dead ice, causing active mixing of the water column and alkalizing the water. Summer seasons were short and the lake was probably not ice-free every year. LM was shallow, poorly populated by benthic diatoms and surrounded by a treeless landscape. Tundra vegetation dominated the lake vicinity until ca. $11.5 \mathrm{cal} \mathrm{ka}$ BP and was replaced by birch forests thereafter (Subetto et al., 2002). The change in vegetation probably indicated a change in moisture availability as well as temperature: a dry, cold climate was replaced by more humid and warmer conditions. After ca. $11.0 \mathrm{cal} \mathrm{ka} \mathrm{BP,} \mathrm{the} \mathrm{last} \mathrm{areas} \mathrm{of} \mathrm{dead} \mathrm{ice} \mathrm{disappeared,}$ birch-pine forests spread, and a more fertile soil cover began to form. Lake water $\mathrm{pH}$ began to shift from alkaline to acidic due to increasing input of humic acids from the forested catchment areas. The increase in available moisture led to a rise of the lake level around ca. $10.6 \mathrm{cal} \mathrm{ka} \mathrm{BP}$; this inference is supported by the increase in abundance of the profundal T. lugens-type. At ca. $10.0 \mathrm{cal} \mathrm{ka} \mathrm{BP}$ it declined, however, indicating a possible lake-level lowering.

Between ca. 10.6 and 10.0 cal ka BP significant changes occurred in the lake's biological communities, following a gradual increase in the content of organic carbon in the bottom sediments (Fig. 2). The rising concentration of organic matter in the sediments (deposition of gyttja) reflects an increase in the productivity of the lake, while input of allochthonous mineral matter from the catchment decreased due to the development of vegetation and soil cover around the lake. After ca. $10.2 \mathrm{cal} \mathrm{ka} \mathrm{BP,} \mathrm{pine,} \mathrm{elm,} \mathrm{and} \mathrm{grey} \mathrm{alder}$ appeared in the forests around the lake, and Poaceae and Cyperaceae dominated grass communities (Subetto, 2009). The hazel and elm likely migrated to the Karelian Isthmus from the west, where they have been previously reported at 10.7 cal ka (Saarse et al., 1996).

\section{Early Holocene (10-8 cal ka BP)}

Reconstructed T July showed a steady warming trend that was interrupted by a slight decline between ca. 8.5 and $8.1 \mathrm{cal} \mathrm{ka}$ $\mathrm{BP}$, with a value of $13.2^{\circ} \mathrm{C}$ at ca. $8.2 \mathrm{cal} \mathrm{ka} \mathrm{BP} \mathrm{(Fig.} \mathrm{4).} \mathrm{This}$ short cooling at ca. $8.2 \mathrm{cal} \mathrm{ka} \mathrm{BP}$ may be associated with "Finse Event" or "8.2 cal ka event" (Alley et al., 1997; Nesje and Dahl, 2001). In response to climate amelioration, the diversity of biological communities grew, while coldstenothermic chironomid taxa declined and were replaced by $C$. ambigua and other taxa characteristic of mesotrophic conditions (Fig. 4 and 5). Cladocera species associated with higher trophic conditions appeared, and there was a sharp decline in the cold-water oligosaprobic taxon B. (E.) longispina, further supporting reconstructed from chironomids temperature increase.

Typical littoral taxa and epiphytes constitute the majority of the cladoceran communities: Alona (A. affinis and A. rectangula/guttata), Alonella (A. excisa and A. nana), and Eurycercus sp. A. excisa and A. nana are commonly recorded in and between Sphagnum plants and A. excisa also occurs in acid waters (Fryer, 1968). Shifts in the biological communities and organic content of the sediment indicate that during the early Holocene the lake was well oxygenated, with high water transparency, as indicated by the presence of C. ambigua.

\section{Middle Holocene (8-4 cal ka BP)}

During this interval, the organic content of the sediments was the highest in the record, indicating the growing productivity of the lake ecosystem (Fig. 2). In the biological communities, the abundance of littoral and phytophilic Cladocera species (A. nana and A. excisa) and the proliferation of chironomid taxa (M. pedellus-type, D. nervosus-type, and Procladius) indicate a moderately warm climate (Fig. 4 and 5). At this time, C. ambigua gradually declined. This was probably due to an increase in biological productivity in LM as a result of climatic amelioration (Digerfeldt, 1986).

Between ca. 8.9 and 7.5 cal ka BP, a change in the dominant cladoceran species from a small $A$. nana to a large sized A. affinis indicates a shift towards K-selected species that typify stable or predictably developing environments (Odum, 1963). After ca. 7.5 cal ka BP, large phytophilic $A$. affinis declined, while A. nana, which is a more flexible pliable vegetation dweller, increased. A. nana has a wider distribution and can tolerate different types of water bodies; from oligo- to eutrophic (Nevalainen, 2008; Smirnov, 2010). There is some evidence that this species can tolerate acidic conditions (Fryer, 1968; however, Sand $\varnothing y$ and Nilssen [1986] disagree). These changes in the taxonomic composition of Cladocera, which include an increase of the phytophilic and acid-tolerant taxa, may indicate a decrease in stability of ecological conditions in the lake, particularly as there is an increase in the ${ }^{\circ}$ disorder of the cladoceran communities after ca. $7.5 \mathrm{cal} \mathrm{ka} \mathrm{BP.} \mathrm{After} \mathrm{ca.} 7.9 \mathrm{cal} \mathrm{ka} \mathrm{BP,} \mathrm{at} \mathrm{the}$ time when the reconstructed $\mathrm{T}$ July reached its highest values, it is likely that the lake littoral areas were overgrown by macrophytes, which, particularly under warm conditions, would encourage paludification processes and possible oxygen depletion.

The reconstructed temperatures were the highest in the record during the middle Holocene period (Fig. 4). Based on this record, the period between ca. 9.5 and 5.5 cal ka BP represents the Holocene thermal maximum (HTM) in the region, with the warmest period centered at ca. $7.8 \mathrm{cal} \mathrm{ka}$ BP. The warming trend started at ca. $10.5 \mathrm{cal} \mathrm{ka} \mathrm{BP.} \mathrm{Air} \mathrm{tem-}$ peratures remained at $14.5-15^{\circ} \mathrm{C}$ until ca. $5.5 \mathrm{cal} \mathrm{ka} \mathrm{BP}$.

\section{Late Holocene (4 cal ka BP-present time)}

The concentration of organic matter remained high until ca. 0.9 cal ka BP (median LOI $=85.4 \%$ ) and decrease thereafter to $42 \%$ (Fig. 2). The proportion of cold-water Cladocera species, such as $A$. harpae and $B$. (E.) longispina, increased after ca. 4.8 cal ka BP (Fig. 5). The chironomid fauna contained both thermophilic eutrophic and cold-stenothermic oligotrophic taxa, suggesting variable in-lake conditions (Fig. 4). However, both chironomid and cladoceran communities demonstrated shifts towards more acidophilic faunas, 
indicating further spreading of overgrown littoral zones with humic waters that remained until modern times. Currently LM has a pH from 5.1 to 5.3 (Trifonova et al., 2014) and the phytoplankton in the lake is dominated by raphidophyte algae, typical of stagnant basins and swamps.

A deterioration of the climate after ca. 5.5 cal ka BP (Fig. 4) corresponds to Neoglacial cooling, which has been observed in various Eurasian and North American regions (Nazarova et al., 2013b; Hoff et al., 2015; Meyer et al., 2015; Syrykh et al., 2017). The lowest T July $\left(13.2^{\circ} \mathrm{C}\right)$ was reconstructed at ca. 0.4 cal ka BP (Fig. 4). Although the low temporal resolution of the sediment profile precludes detailed tracking of such events as the Medieval Climate Anomaly or Little Ice Age (LIA), we can speculate that this cooling may be associated with the LIA on the Karelian Isthmus and the higher value reconstructed from the modern sample fits twentiethcentury warming.

\section{Regional comparison}

\section{Late Pleistocene/Holocene transition (12.3-10.0 cal ka $B P)$}

A dry and cold climate dominated northern Europe before the deposition of Vedde ash at ca. 12.0 cal ka BP (Mangerud et al., 1984). According to many records, there was a rapid warming in the North Atlantic region at about $11.5 \mathrm{cal} \mathrm{ka}$ BP (Björck et al., 1998; Walker et al., 1999); however, no rapid warming is recorded on the Karelian Isthmus. Some climatic improvement, i.e., a small increase in the air temperature and humidity, occurred at a maximum date of $11.0 \mathrm{cal}$ ka BP (Subetto et al., 2003). In the LM record, the beginning of the warming trend occurred even later, after $10.5 \mathrm{cal}$ ka BP. This delay was also found in southern Finland, where noticeable warming was observed at ca. 10.8-10.2 cal ka (Bondestam et al., 1994; Luoto et al., 2010).

Strong easterly winds blowing south of the SIS could reinforce anticyclonic circulation (Yu and Harrison, 1995). At ca. 11.6-9.7 cal ka BP, gradual final demise of the SIS enabled the progressive spread of North Atlantic air masses to the northwestern regions of Russia (Peterson, 1994; Stroeven et al., 2016). The approximate time of these events is comparable to our data, which indicated a cold climate before ca. $10.5 \mathrm{cal} \mathrm{ka} \mathrm{BP}$ and an increasing warming afterwards.

\section{Early Holocene (ca. 10.0-8.0 cal ka BP)}

The melting of glaciers and permafrost and the onset of warming at ca. 10.5-10.0 cal ka BP influenced the ecological conditions across the region. The breakthrough of the Baltic Ice Lake due to the retreat of the glacier near Mt. Billingen, in central Sweden, ca. 11.5 cal ka BP (Björck, 1995) led to a sharp (25-28 m) drop in water level. As a result of the rapid and catastrophic fall in the level of the BIL, large areas drained, including the Karelian Isthmus. At the same time, the climate abruptly changed from the cold and relatively dry climate of the Late Glacial to the warm and relatively humid conditions of the Holocene (Subetto et al., 2003).

On the central and southern Kola Peninsula, summer temperatures rose in the early Holocene (Ilyashuk et al., 2005, 2013). In southern Finland, pollen-based reconstructions indicated temperatures $7^{\circ} \mathrm{C}$ colder than present during the early Holocene (ca. 10.7-8 cal ka BP; Heikkilä and Seppä, 2003). However, due to the slower response of vegetation to climate change compared to chironomids (Massaferro and Brooks, 2002), this may be an overestimation and the chironomid-inferred early Holocene temperatures of $3^{\circ} \mathrm{C}$ colder than present might be closer to the real conditions (Luoto et al., 2010). This is further supported by the LM sedimentary record, where the chironomid-based reconstruction also showed the early Holocene T July as ca. $3-4^{\circ} \mathrm{C}$ colder than at present.

A short cooling reconstructed between ca. 8.5 and $8.1 \mathrm{cal}$ ka BP with the lowest T July $\left(13.2^{\circ} \mathrm{C}\right)$ at ca. 8.2 cal ka BP was registered in the LM record. It may be associated with " 8.2 cal ka event" and is related to the glacial expansion episode that took place prior to the HTM at ca. 8.3-8.1 cal ka BP (Bakke et al., 2005). This is the first finding for the area although this event was widely reported from different proxy records in the North Atlantic region (Alley et al., 1997; Seppä and Poska, 2004; Ojala and Alenius, 2005) and was previously found in adjacent areas of Eastern Fennoscandia (Alley et al., 1997; Ilyashuk et al., 2013). A cold period culminating in ca. $8.2 \mathrm{cal}$ ka has been found in southern Finland (Alley et al., 1997). Early Holocene warming on the Kola Peninsula was also interrupted by a cooling between ca. 8.5 and 8.0 cal ka BP, when summer temperatures in the Khibiny Mountains were at least $1^{\circ} \mathrm{C}$ colder than those of the adjoining time intervals (Ilyashuk et al., 2013).

\section{Middle Holocene (8.0-4.0 cal ka BP)}

The HTM is recorded at different times across western Fennoscandia-between 9 and 4 cal ka, with local variation among sites and regional differences in moisture availability between southern and northern Finland during the Holocene (Koc and Jansen, 1994; Jiang et al., 1997; Seppä and Birks, 2001; Ojala and Alenius, 2005; Antonsson et al., 2006; Luoto et al., 2010).

In contrast to western Fennoscandia, the more eastern areas of Russian Fennoscandia demonstrated a relatively similar moisture availability and climatic pattern in the middle Holocene (Solovieva and Jones, 2002; Ilyashuk et al., 2005). In the LM record, the warmest and driest period was recorded at ca. 7.9-5.4 cal ka BP, with T July $\sim 1^{\circ} \mathrm{C}$ higher than at present. In the Khibiny Mountains (central Kola Peninsula), a relatively warm climate prevailed between ca. 9.5 and 5.4 cal ka. On the southern Kola Peninsula, summers remained relatively warm between ca. 8.4 and $6.0 \mathrm{cal} \mathrm{ka} \mathrm{BP,} \mathrm{with} \mathrm{a} \mathrm{lowering} \mathrm{of} \mathrm{lake} \mathrm{lev-}$ els between ca. 7.0 and 4.0 cal ka BP (Ilyashuk et al., 2005). In the west-central part of the Kola Peninsula (Solovieva and Jones, 2002), the climate was warmer and drier than at present between ca. 9.0 and $5.0 \mathrm{cal} \mathrm{ka}$ BP. In the northwest of the 
Kola Peninsula, lowered lake levels were recorded at ca. 7.35.2 cal ka BP (Boettger et al., 2003). In Lake Ladoga, the highest $\delta^{18} \mathrm{O}$ diatom values (ca. $+34.7 \pm 0.1 \%$ o ) were observed in the oxygen isotope curve between ca. 7.1 and 5.7 cal ka BP. This most likely corresponds to the HTM (Kostrova et al., 2019).

The observed changes from moister early Holocene conditions towards warmer and drier conditions in the middle Holocene suggest that the dominating atmospheric circulation over northern Europe and the adjacent northern seas could have changed during the early to middle Holocene transition (Ojala et al., 2008). A summer circulation mode associated with dry summers resulted from stagnant highpressure conditions over eastern Fennoscandia (Davis et al., 1997; Chen and Hellström, 1999; Ojala et al., 2008), which could explain the reconstructed pattern of summer temperatures and moisture availability in the LM records as well as in other records from Scandinavia and adjacent regions.

\section{Late Holocene (4.0 cal ka BP-present time)}

Neoglacial cooling trend is evident in the LM record after ca. $5.5 \mathrm{cal} \mathrm{ka} \mathrm{BP}$ and the coldest period is reconstructed between ca. 3.3 and $2.8 \mathrm{cal} \mathrm{ka}$ BP with the July temperature ca. $2-3^{\circ} \mathrm{C}$ cooler than present. Eastern Fennoscandia seems to demonstrate late Holocene climatic pattern similar to the LM record. North of the Karelian Isthmus, at the Kola Peninsula, the cooling trend started at ca. $5.4 \mathrm{cal} \mathrm{ka} \mathrm{BP}$, with the last four millennia representing the coldest period during the last $10.0 \mathrm{ka}$; particularly cold summers occurred between ca. 3.2-1.5 cal ka BP (Ilyashuk et al., 2005, 2013). A continuous depletion in $\delta^{18} \mathrm{O}$ diatom record from Lake Ladoga (east of Karelian Isthmus) started ca. $6.1 \mathrm{cal} \mathrm{ka} \mathrm{BP}$ and accelerated after ca. 4 cal ka BP, responding to late Holocene cooling (Kostrova et al., 2019). In western Fennoscandia, an onset of Neoglacial cooling occurred with some temporal variability around 5-4 cal ka BP, with the coldest period frequently reconstructed between ca. 3 and 1 cal ka BP (Korhola, 1995; Jiang et al., 1997; Tiljander et al., 2003; Heikkilä and Seppä, 2003; Ojala and Alenius, 2005; Antonsson et al., 2006; Ojala et al., 2008; Luoto et al., 2010).

The late Holocene cooling trend across Fennoscandia is related to the breakup of the long-standing stable atmospheric circulation with a dominant westerly airflow and moisture sourcing from the North Atlantic Ocean about ca. $5.3 \mathrm{cal}$ $\mathrm{ka}$ BP. This was accompanied by the activation of air masses from the Arctic Ocean and Baltic Sea (Seppä and Birks, 2001, 2002; Wanner et al., 2008; Thienemann et al., 2019), forest retreat, and climate humidification relating to the expansion of peatlands (Hammarlund et al., 2004; Weckström et al., 2010; Väliranta et al., 2011). The acidification trend was prominent in the lakes of the Kola Peninsula during the last ca. $3 \mathrm{ka}$ as well: following the HTM, low July temperatures were accompanied by the onset of natural acidification (Ilyashuk et al., 2005, 2013) following a gradual increase in humic acid input. This is further supported by our data and, in particular, through changes in chironomid and Cladocera assemblages towards more cold- and acid-tolerant taxa suggesting a catchment paludification during this period.

\section{CONCLUSIONS}

Our multiproxy study of a sediment core from a lake on the Karelian Isthmus (southeastern Fennoscandia) provided evidence of a highly variable Holocene environment and contributed to the spatial understanding of Holocene climate dynamics and climate-forcing mechanisms in the region. At the late Pleistocene/early Holocene transition mean July air $\mathrm{T}$ was $3-4^{\circ} \mathrm{C}$ below modern level. The lowest diversity of chironomids and Cladocera communities reflected a developing environment following deglaciation. The proximity of the SIS, widespread permafrost, possible stagnant ice, cold surface waters of the BIL surrounding the Karelian Isthmus, and regional atmospheric circulation patterns may all have contributed to the $0.5-1$ ka delay in the onset of climate amelioration on the Karelian Isthmus. The breakpoints in the DCA axis 1 scores at ca. 10.6 and $9.17 \mathrm{cal} \mathrm{ka} \mathrm{BP}$ indicated shifts in biological communities in response to climate amelioration. At this time, the concentration of organic matter in sediments increased sharply and the lake underwent a transition from an oligotrophic to mesotrophic state, characterized by a strong dominance of $C$. ambigua/M. pedellustype. Similar phases have been seen in numerous lakes across Fennoscandia. After ca. 10.5 cal ka BP, a dry, cold climate was replaced by more humid and warm conditions that were interrupted by a slight decline between ca. 8.5 and $8.1 \mathrm{cal} \mathrm{ka} \mathrm{BP}$, which might be related to the $8.2 \mathrm{ka}$ cooling event. Despite moisture availability mismatches previously found in western Fennoscandia, the eastern areas of Russian Fennoscandia demonstrated relatively similar climatic patterns: a humid early Holocene and a dry and warm second half of the middle Holocene. Changes in atmospheric circulation during the early to middle Holocene transition and the onset of stagnant high-pressure conditions over eastern Fennoscandia could explain the decreasing moisture availability reconstructed from many records of eastern Fennoscandia. The period between ca. 9.5 and 5.5 cal ka BP can be associated with the HTM with the warmest period centered at ca. $7.8 \mathrm{cal} \mathrm{ka} \mathrm{BP}$. Air temperatures remained stable at a level of $14.5-15^{\circ} \mathrm{C}$ until ca. $5.5 \mathrm{cal} \mathrm{ka}$ $\mathrm{BP}$, when the climate deteriorated in association with Neoglacial cooling. The $3.12 \mathrm{cal} \mathrm{ka}$ BP breakpoint in the chironomid community indicated a shift from middle Holocene mesotrophic and thermophilic fauna to mostly phytophilic and acid-tolerant taxa in response to the intensification of paludification and acidification processes in the lake during the late Holocene. T July rose towards the present-day with a short-term decline at ca. $0.4 \mathrm{cal} \mathrm{ka}$ BP. This decline may correspond to the LIA on the Karelian Isthmus. In general, the Holocene climate variability on the Karelian Isthmus was relatively consistent with the climate records from Fennoscandia and provided further evidence for the changing North Atlantic Ocean-atmosphere circulation throughout the Holocene. 


\section{ACKNOWLEDGMENTS}

We thank all Russian colleagues who helped us during the fieldwork. This study was supported by Deutsche Forschungsgemeinschaft (DFG) Project NA 760/5-1 and DI 655/9-1 and by the grant of the Russian Science Foundation (Grant 16-17-10118). LF, LS, IG and DS were supported by RFBR (research project 18-05-00406, 18-55-00008 Bel_a, 18-05-80087). Our sincere thanks to Julie Bringham-Grette and the anonymous reviewer for their valuable comments.

\section{SUPPLEMENTARY MATERIAL}

The supplementary material for this article can be found at https:// doi.org/10.1017/qua.2019.88.

\section{REFERENCES}

Aleksandrovskii, A.L., Arslanov, Kh.A., Davydova, N.N., Doluchanov, P.M., Zaitseva, G.I., Kirpichnikov, A.N., Kuznetsov, D.D., et al., 2009. New data on the Ladoga transgression, the Neva River formation, and agricultural development of Northwestern Russia. Doklady Earth Sciences 425, 274-278.

Alley, R.B., Mayewski, P.A., Sowers, T., Stuiver, M., Taylor, K.C., Clark, P.U., 1997. Holocene climatic instability: A prominent, widespread event 8200 years ago. Geology 25, 483-486.

Andersson, S., Rosqvist, G., Leng, M., Wastegard, S., Blaauw, M., 2010. Late Holocene climate change in central Sweden inferred from lacustrine stable isotope data. Journal of Quaternary Science $25,1305-1316$.

Andronikov, A., Subetto, D., Lauretta, D., Andronikova, I., Rudnickaite, E., Drosenko, D., Syrykh, L., 2014. In search for fingerprints of an extraterrestrial event: Trace element characteristics of sediments from the Lake Medvedevskoye (Karelian Isthmus, Russia). Doklady Earth Sciences 1, 819-823.

Antonsson, K., Brooks, S.J., Seppä, H., Telford, R.J., Birks, H.J.B., 2006. A quantitative palaeotemperature records inferred from fossil pollen and chironomid assemblages from Lake Gilltjärnen, northern central Sweden. Journal of Quaternary Science 21, 831841.

Bakke, J., Dahl, S.O., Paasche, Ø., Løvlie, R., Nesje, A., 2005. Glacier fluctuations, equilibrium-line altitudes and palaeoclimate in Lyngen, northern Norway, during Lateglacial and Holocene. The Holocene 15, 518-540.

Bennett, K.D., 1996. Determination of the number of zones in a biostratigraphical sequence. New Phytologist 132, 155-170.

Birks, H.J.B., 1995. Quantitative palaeoenvironmental reconstructions. In: Maddy, D., Brew, J.S. (Eds.), Statistical Modelling of Quaternary Science Data. Quaternary Research Association, Cambridge, pp. 161-254.

Birks, H.J.B., 1998. Numerical tools in palaeolimnology-progress, potentialities, and problems. Journal of Paleolimnology 20, 307-332.

Birks, H.J.B., Gordon, A.D., 1985. The analysis of pollen stratigraphical data: Zonation. In: Birks, H.J.B., Gordon, A.D. (Eds.), Numerical Methods in Quaternary Pollen Analysis, Academic Press, London, pp. 47-90.

Birks, H.J.B., Line, J.M., Juggins, S., Stevenson, A.C., ter Braak, C.J.F., 1990. Diatoms and $\mathrm{pH}$ reconstruction. Philosophical Transactions of the Royal Society of London, Series B 327, 263-278.
Björck, S., Walker, M.J.C., Cwynar, L.C., Johnsen, S., Knudsen, K.-L., Lowe, J.J., Wohlfarth, B., 1998. INTIMATE members. An event stratigraphy for the Last Termination in the North Atlantic region based on the Greenland ice core record: A proposal by the INTIMATE group. Journal of Quaternary Science 13, 283 292.

Björck, S.A., 1995. Review of the history of the Baltic Sea, 13.0 8.0 ka BP. Quaternary International Journal 27, 19-40.

Blaauw, M., Christen, J.A., 2011. Flexible paleoclimate age-depth models using an autoregressive gamma process. Bayesian Analysis 6, 457-474.

Boettger, T., Hiller, A., Kremenetski, K., 2003. Mid-Holocene warming in the northwest Kola Peninsula, Russia: Northern pinelimit movement and stable isotope evidence. The Holocene 13, 403-408.

Bondestam, K., Vasari, A., Vasari, K., Lemdahl, G., Eskonen, K., 1994. Younger Dryas and Preboreal in Salpausselkä Foreland, Finnish Karelia. Dissertations Botanicae 234, 161-206.

Brodersen, K.P., Dall P.C., Lindegaard, C., 1998. The invertebrate fauna in the upper stony littoral of Danish lakes: macroinvertebrates as trophic indicators. Freshwater Biology 39, 577592.

Brodersen, K.P., Lindegaard, C., 1999. Mass occurrence and sporadic distribution of Corynocera ambigua Zettersedt (Diptera, Chironomidae) in Danish lakes. Neo and palaeolimnological records. Journal of Paleolimnology 22, 41-52.

Brooks, S.J., Birks, H.J.B., 2001. Chironomid inferred air temperature from late glacial and Holocene sites in north-west Europe: Progress and problems. Quaternary Science Reviews 20, 1723 1741.

Brooks, S.J., Langdon, P.G., Heiri, O., 2007. The Identification and Use of Palaearctic Chironomidae Larvae in Palaeoecology. QRA Technical Guide, No. 10. Quaternary Research Association, London.

Chen, D., Hellström, C., 1999. The influence of the North Atlantic Oscillation on the regional temperature variability in Sweden: Spatial and temporal variations. Tellus 51A, 505-516.

Davis, B., Kelly, P.M., Osborn, T., 1997. Explaining the climate of the British Isles. In: Hulme, M. and Barrow, E. (Eds.), Climates of the British Isles: Past, Present and Future. Routledge, London, pp. 11-32.

Davydova, N.N., Arslanov, K.A., Khomutova, V.I., Krasnov, I.I., Malakhovsky, D.V., Saarnisto, M., Saksa, A.I., Subetto, D.A., 1996. Late- and postglacial history of lakes of the Karelian Isthmus. Hydrobiologia 322, 199-204.

Diekmann, B., Pestryakova, L., Nazarova, L., Subetto, D., Tarasov, P., Stauch, G., Thiemann, A., et al., 2016. Late Quaternary Lake Dynamics in the Verkhoyansk Mountains of Eastern Siberia: Implications for Climate and Glaciation History. Polarforschung $86,97-110$

Digerfeldt, G., 1986. Studies on past lake-level fluctuations. In: Berglund, B.E. (Ed.), Handbook of Holocene Palaeoecology and Palaeohydrology. John Wiley and Sons, New York, pp. 127-144.

Doncaster, C.P., Chávez, V.A., Viguier, C., Wang, R., Zhang, E., Dong, X., Dearing, J.A., Langdon, P.G., Dyke, J.G., 2016. Early warning of critical transitions in biodiversity from compositional disorder. Ecology 97, 3079-3090.

Flössner, D., 2000. Die Haplopoda und Cladocera (ohne Bosminidae) Mitteleuropas. Backhuys Publishers, Leiden.

Forsberg, C., 1965. Nutritional studies Chara in axenic cultures. Physiologia Plantarum 18, 275-290. 
Frey, D.G., 1959. The taxonomic and phylogenic significance of the head pores of the Chidoridae (Cladocera). Internationale Revue der gesamten Hydrobiologie und Hydrographie 44, 27-60.

Frey, D.G., 1973. Comparative morphology and biology of three species of Eurycercus (Cladocera,Chydoridae) with a description of Eurycercus macracanthus sp. nov. Internationale Revue der gesamten Hydrobiologie und Hydrographie 58, 221-267.

Frolova, L., Nazarova, L., Pestryakova, L., Herzschuh, U., 2014. Subfossil cladoceran remains from sediment in thermokarst lakes in northeastern Siberia, Russia. Journal of Paleolimnology 52, 107-119.

Frolova, L., Nazarova, L., Zinnatova, E., Frolova, A., Herzschuh, U., 2017a. Cladocera remains from sediments of thermokarst lakes of north-central Siberia (RUSSIA). 17th International Multidisciplinary Scientific GeoConference SGEM 17, 211-218.

Frolova, L.A., 2016. Subfossil Cladocera (Branchiopoda, Crustacea) in climatic and palaeoenvironmental investigations in Eastern Siberia (Russia). 16th International Multidisciplinary Scientific GeoConference SGEM 2, 601-606.

Frolova, L.A., Ibragimova, A.G., Ulrich, M. and Wetterich, S., 2017b. Reconstruction of the history of a thermokarst lake in the Mid-Holocene based on an analysis of subfossil Cladocera (Siberia, Central Yakutia). Contemporary Problems of Ecology 10, 423-430.

Frolova, L.A., Nazarova L., Pestryakova L., Herzschuh U., 2013. Analysis of the effects of climate-dependent factors on the formation of zooplankton communities that inhabit arctic lakes in the Anabar River Basin. Contemporary Problems of Ecology 6, 1-11.

Fryer, G., 1968. Evolution and adaptive radiation in the Chydoridae (Crustacea. Cladocera) a study in comparative functional morphology and ecology. Philosophical Transactions of the Royal Society of London. Series B, Biological Sciences 254, 221-385.

Gromig, R., Wagner, B., Wennrich, V., Fedorov, G., Savelieva, L., Lebas, E., Krastel, S., Brill, D., Andreev, A., Subetto D., Melles M., 2019. Deglaciation history of Lake Ladoga (northwestern Russia) based on varved sediments. Boreas 48, 330-348.

Hammarlund, D., Velle, G., Wolfe, B.B., Edwards, T.W.D., Barnekow, L., Bergman, J., Holmgren, S., Lamme, S., Snowball, J., Wohlfarth, B., Possnert, G., 2004. Palaeolimnological and sedimentary responses to Holocene forest retreat in the Scandes Mountains, west-central Sweden. Holocene 14, 862-876.

Hang, T., 1997. Clay varve chronology in the Eastern Baltic area. Geografiska Föreningens i Stockholm Förhandlingar 119, 295300.

Hang, T., Subetto, D., Krasnov, I., 2000. New varvochronological data for the NW Russia. [In Russian.] Proceedings of the Russian Geographical Society 132, 37-42.

Heikkilä, M., Seppä, H., 2003. A 11,000 yr palaeotemperature reconstruction from the southern boreal zone in Finland. Quaternary Science Reviews 22, 541-554.

Heiri, O., Lotter, A.F., 2001. Effect of low count sums on quantitative environmental reconstructions: An example using subfossil chironomids. Journal of Paleolimnology 26, 343-350.

Heiri, O., Lotter, A.F., Lemcke, G., 2001. Loss on ignition as a method for estimating organic and carbonate content in sediments: Reproducibility and comparability of results. Journal of paleolimnology 25(1), 101-110.

Hill, M.O., 1973. Diversity and evenness: A unifying notation and its consequences. Ecology 54, 427-432.

Hoff, U., Biskaborn, B.K., Dirksen, V., Dirksen, O., Kuhn, G., Meyer, H., Nazarova, L., Roth, A., Diekmann, B., 2015. Holocene Environment of Central Kamchatka, Russia: Implications from a multi-proxy record of Two-Yurts Lake. Global and Planetary Change 134, 101-117.

Ilyashuk, B.P., Ilyashuk, E.A., 2007. Chironomid record of Late Quaternary climatic and environmental changes from two sites in Central Asia (Tuva Republic, Russia)-local, regional or global causes? Quaternary Science Reviews 26, 705-731.

Ilyashuk, E.A., Ilyashuk, B.P., Hammarlund, D., Larocque, I., 2005. Holocene climatic and environmental changes inferred from midge records (Diptera: Chironomidae, Chaoboridae, Ceratopogonidae) at Lake Berkut, southern Kola Peninsula, Russia. The Holocene 15, 897-914.

Ilyashuk, E.A., Ilyashuk, B.P., Kolka V.V., Hammarlund, D., 2013. Holocene climate variability on the Kola Peninsula, Russian Subarctic, based on aquatic invertebrate records from lake sediments. Quaternary Research 79, 350-361.

Jiang, H., Björck, S., Knudsen, K.L., 1997. A palaeoclimatic and palaeoceanographic record of the last $1100014 \mathrm{C}$ years from the Skagerrak-Kattegat, northeastern Atlantic margin. The Holocene 7, 301-310.

Juggins, S., 2007. Version 1.5 User guide. Software for ecological and palaeoecological data analysis and visualization. Newcastle University, Newcastle upon Tyne.

Kattel, G.R., Sirocko, F., 2011. Palaeocladocerans as indicators of environmental, cultural and archaeological developments in Eifel maar lakes region (West Germany) during the Lateglacial and Holocene periods. Hydrobiologia 676, 203.

Kienast, F., Wetterich, S., Kuzmina, S., Schirrmeister, L., Andreev, A., Tarasov, P., Nazarova, L., Kossler, A., Frolova, L., Kunitsky, V., 2011. Paleontological records prove boreal woodland under dry inland climate at today's Arctic coast in Beringia during the last interglacial. Quaternary Science Reviews 30, 2134-2159.

Koc, N., Jansen, E., 1994. Response of the high-latitude Northern Hemisphere to orbital climate forcing: Evidence from the Nordic seas. Geology 22, 523-526.

Korhola, A., 1995. Holocene climatic variations in southern Finland reconstructed from peat-initiation data. The Holocene 5, 43-58.

Korhola, A., 1999. Distribution patterns of Cladocera in subarctic Fennoscandian lakes and their potential in environmental reconstruction. Ecography 22, 357-373.

Korhola, A., Rautio, M., 2001. Cladocera and other branchiopod crustaceans. In: Name(s) (Ed[s].), Tracking environmental change using lake sediments. Vol. 4. Zoological indicators. Kluwer Academic Publishers, Dordrech, pp. 125-165.

Kostrova, S.S., Meyer, H., Bailey, H.L., Ludikova, A.V., Gromig, R., Kuhn, G., Shibaev, Y.A., Kozachek, A.V., Ekaykin, A.A., Chapligin, B., 2019. Holocene hydrological variability of Lake Ladoga as inferred from diatom oxygen isotopes. Boreas 48, 361-376.

Kotov, A.A., Sinev, A.Y., Glagolev, S.M., Smirnov, N.N., 2010. Water fleas (Cladocera). In: Alexeev V.R., Tsalolokhin S.Y. (eds.), Key book for zooplankton and zoobenthos of fresh waters of European Russia. KMK, Moscow. pp. 151-276.

Kuznetsov, D.D., 2014. Transformation of Palaeobasins on Karelian Isthmus in Late Neopleistocene and Holocene (According to Lake Sediment Analysis). [In Russian.] PhD dissertation, Limnological Institute, St. Petersburg.

Langdon, P.G., Ruiz, Z., Brodersen, K.P., Foster, I.D.L., 2006. Assessing lake eutrophication using chironomids: Understanding the nature of community response in different lake types. Freshwater Biology 51, 562-577. 
Larocque, I., 2001. How many chironomid head capsules is enough? A statistical approach to determine sample size for paleoclimatic reconstruction. Palaeogeography, Palaeoclimatolog, Palaeoecology 172, 133-142.

Lotter, A.F., Birks, H.J.B., Hofmann, W., Marchetto, A., 1998. Modern diatom, cladocera, chironomid, and chrysophyte cyst assemblages as quantitative indicators for the reconstruction of past environmental conditions in the Alps. II. Nutrients. Journal of Paleolimnology 19, 443-463.

Lotter, A.F., Juggins, S., 1991. POLPROF, TRAN and ZONE: Programs for plotting, editing and zoning pollen and diatom data. INQUA-Subcommission for the study of the Holocene Working Group on Data-Handling Methods, Newsletter 6, 4-6.

Luoto, T.P., Kultti, S., Nevalainen, L., Sarmaja-Korjonen, K., 2010. Temperature and effective moisture variability in southern Finland during the Holocene quantified with midge-based calibration models. Journal of Quaternary Science 25, 1317-1326.

Mangerud, J., Lie, S.E., Furners, H., Kristiansen, I.L., Lømo, L., 1984. A Younger Dryas ash bed in western Norway and its possible correlations with tephra in cores from the Norwegian Sea and the North Atlantic. Quaternary Research 21, 85-104.

Markov, K.K., Krasnov, I.I., 1930. Geochronological study of layered sediments in the northwestern region of the USSR. Bulletin of the Commission of the Study of the Quaternary Period 2, 27-46.

Massaferro, J., Brooks, S.J., 2002. Response of chironomids to Late Quaternary environmental change in the Taitao Peninsula, southern Chile. Journal of Quaternary Science 17, 101-111.

Meyer, H., Chapligin B., Hoff, U., Nazarova, L., Diekmann, B., 2015. Oxygen isotope composition of diatoms as Late Holocene climate proxy at Two-Yurts-Lake, Central Kamchatka, Russia. Global and Planetary Change 134, 118-128.

Meyer-Jacob, C., Bindler, R., Bigler, C., Leng, M.J., Lowick, S.E. and Vogel, H., 2017. Regional Holocene climate and landscape changes recorded in the large subarctic lake Torneträsk, N Fennoscandia. Palaeogeography, Palaeoclimatology, Palaeoecology 487, 1-14.

Moller Pillot, H.K.M., 2009. Chironomidae Larvae. Volume 2: Biology and Ecology of the Chironomini. KNNV Publishing, Zeist.

Nazarova, L., Bleibtreu, A., Hoff, U., Dirksen, V., Diekmann, B., 2017b. Changes in temperature and water depth of a small mountain lake during the past 3000 years in Central Kamchatka reflected by chironomid record. Quaternary International 447, 46-58.

Nazarova, L., de Hoog, V., Hoff, U., Diekmann, B., 2013b. Late Holocene climate and environmental changes in Kamchatka inferred from subfossil chironomid record. Quaternary Science Reviews 67, 81-92.

Nazarova, L., Herzschuh, U., Wetterich, S., Kumke, T., Pestjakova, L., 2011. Chironomid-based inference models for estimating mean July air temperature and water depth from lakes in Yakutia, northeastern Russia. Journal of Paleolimnology 45, 57-71.

Nazarova, L., Lüpfert, H., Subetto, D., Pestryakova, L., Diekmann, B., 2013a. Holocene climate conditions in Central Yakutia (North-Eastern Siberia) inferred from sediment composition and fossil chironomids of Lake Temje. Quaternary International 290-291, 264-274.

Nazarova, L., Self, A., Brooks, S.J., van Hardenbroek, M., Herzschuh, U. and Diekmann, B., 2015. Northern Russian chironomid-based modern summer temperature data set and inference models. Global Planetary Change 134, 10-25.
Nazarova, L., Subetto, D., Syrykh, L.S., Grekov, I.M., Leontev, P.A., 2018. Reconstructions of palaeoecological and palaeoclimatic conditions of the Late Pleistocene and Holocene according to the results of chironomid analysis of sediments from Medvedevskoe Lake (Karelian Isthmus). Doklady Earth Sciences 480, 710-714.

Nazarova, L.B., Pestryakova, L.A., Ushnitskaya, L.A., Hubberten, H.-W., 2008. Chironomids (Diptera: Chironomidae) in lakes of Central Yakutia and their indicative potential for paleoclimatic research. Contemporary Problems of Ecology 1, 335-345.

Nazarova, L.B., Self, A.E., Brooks, S.J., Solovieva, N., Syrykh, L.S., Dauvalter, V.A., 2017a. Chironomid fauna of the lakes from the Pechora River Basin (East of European part of Russian Arctic): Ecology and reconstruction of recent ecological changes in the region. Contemporary Problems of Ecology 10, 350-362.

Nesje, A., Dahl, S.O., 2001. The Greenland 8200 cal. yr BP event detected in loss-on-ignition profiles in Norwegian lacustrine sediment sequences. Journal of Quaternary Science 16, 155-166.

Nevalainen, L., 2008. Sexual reproduction in chydorid cladocerans (Anomopoda, Chydoridae) in southern Finland_implications for paleolimnology. PhD thesis Department of Geology, University of Helsinki, University of Helsinki, Helsinki.

New, M., Lister, D., Hulme, M., Makin, I., 2002. A high-resolution data set of surface climate over global land areas. Climate Research 21, 1-25.

Odum, E.P., 1963. Ecology. Holt, Rinehart and Winston, New York.

Ojala, A.E.K., Alenius, T., 2005. 10000 years of interannual sedimentation recorded in the Lake Nautajärvi (Finland) clasticorganic varves. Palaeogeography, Palaeoclimatology, Palaeoecology 219, 285-302.

Ojala, A.E.K., Alenius, T., Seppä, H., Giesecke, T., 2008. Integrated varve and pollen-based temperature reconstruction from Finland: evidence for Holocene seasonal temperature patterns at high latitudes. The Holocene 18, 529-538.

Oksanen, J., Blanchet, F.G., Friendly, M., Kindt, R., Legendre, P., McGlinn, D., Minchin, P.R., et al., 2017. Vegan: Community ecology package. $\mathrm{R}$ package version 2.4-5. https://CRAN.Rproject.org/package=vegan.

Palagushkina, O.V., Nazarova, L.B., Wetterich, S., Shirrmaister, L., 2012. Diatoms of modern bottom sediments in Siberian Arctic. Contemporary Problems of Ecology 5, 413-422.

Palagushkina, O., Wetterich, S., Schirrmeister, L., Nazarova, L., 2017. Modern and fossil diatom assemblages from Bol'shoy Lyakhovsky Island (New Siberian Archipelago, Arctic Siberia). Contemporary Problems of Ecology 4, 380-394.

Peterson, G.M., 1994. Vegetational and climatic history of the western Former Soviet Union. In: Wright, H.E., Jr., Kutzbach, J.E., Webb, T., III, Ruddiman, W.F., Street-Perrott, F.A., Bartlein, P.J. (Eds.), Global Climates Since the Last Glacial Maximum, 169-193.

Plikk, A., Engels S., Luoto T., Nazarova L., Salonen J.S., Helmens K.F., 2019. Chironomid-based temperature reconstruction for the Eemian Interglacial (MIS 5e) at Sokli, northeast Finland. Journal of Paleolimnology 61, 355-371.

Quinlan, R., Smol, J.P., 2001. Setting minimum head capsule abundance and taxa deletion criteria in chironomid-based inference models. Journal of Paleolimnology 26, 327-342.

R Core Team, 2012. R: A Language and Environment for Statistical Computing. R Foundation for Statistical Computing, Vienna.

Reimer, P.J., Bard, E., Bayliss, A., Beck, J.W., Blackwell, P.G., Bronk Ramsey, C., Buck, C.E., et al., 2013. IntCal13 and 
Marine13 radiocarbon age calibration curves $0-50,000$ years cal. BP. Radiocarbon 55, 1869-1887.

Rinterknecht, V., Hang, T., Gorlach, A., Kohv, M., Kalla, K., Kalm, V., Subetto, D., Bourlès, D., Lèeanni, L., Guillou, V., and ASTER Team, 2018. The Last Glacial Maximum extent of the Scandinavian Ice Sheet in the Valday Heights, western Russia: Evidence from cosmogenic surface exposure dating using ${ }^{10} \mathrm{Be}$. Quaternary Science Reviews 200, 106-113.

Rodriguez-Girones, M.A., Santamaria, L., 2006. A new algorithm to calculate the nestedness temperature of presence-absence matrices. Journal of Biogeography 33, 924-935.

Rosqvist, G., Jonsson, C., Yam, R., Karlen, W., Shemesh, A., 2004. Diatom oxygen isotopes in pro-glacial lake sediments from northern Sweden: A 5000 year record of atmospheric circulation. Quaternary Science Reviews 23, 851-859.

Rosqvist, G., Leng, M.J., Jonsson, C., 2007. North Atlantic region atmospheric circulation dynamics inferred from a late-Holocene lacustrine carbonate isotope record, northern Swedish Lapland. The Holocene 17, 867-873.

Saarnisto M., Saarinen T., 2001. Deglaciation chronology of the Scandinavian Ice Sheet from the Lake Onega Basin to the Salpausselkä end Moraines. Global and Planetary Change 31, 387-405.

Saarse, L., Mäemets, H., Pirrus, R., Rõuk, A.M., Sarv, A., Ilves, E., (1996) Estonia. In: Berglund BE, Birks HJB, RalskaJasiewiczowa M, Wright HE (Eds) Palaeoecological events during the last 15000 years. Regional syntheses of palaeoecological studies of lakes and mires in Europe. Wiley, Chichester, pp. 367393

Sandøy, S., Nilssen, J.P. 1986. A geographical survey of littoral crustacea in Norway and their use in paleolimnology. Hydrobiologia 143, 277-286.

Savelieva, L.A., Andreev, A.A., Gromig, R., Subetto, D.A., Fedorov, G.B., Wennrich, V., Wagner, B., Melles, M., 2019. Vegetation and climate changes in northwestern Russia during the Lateglacial and Holocene inferred from the Lake Ladoga pollen record. Boreas 48, 349-360.

Seppä, H., Birks, H.J.B., 2001. July mean temperature and annual precipitation trends during the Holocene in the Fennoscandian tree-line area: pollen-based climate reconstruction. The Holocene 11, 527-539.

Seppä, H., Birks, H.J.B. 2002. Holocene climate reconstructions from the Fennoscandian tree-line area based on pollen data from Toskaljavri. Quaternary Research 57, 191-199.

Seppä, H., Poska A., 2004. Holocene annual mean temperature changes in Estonia and their relationship to solar insolation and atmospheric circulation patterns. Quaternary Research 61, 22-31.

Shemesh, A., Rosqvist, G., Rietti-Shati, M., Rubensdotter, L., Bigler, C., Yam, R., Karlen, W., 2001. Holocene climatic change in Swedish Lapland inferred from an oxygen-isotope record of lacustrine biogenic silica. The Holocene 11, 447-454.

Smirnov, N.N., 2010. Historical Ecology of the Freshwater Zoocenoses. Partnership of Scientific Publications KMK, Moscow.

Solovieva, N., Jones, V., 2002. A multiproxy record of Holocene environmental changes in the central Kola Peninsula, northwest Russia. Journal of Quaternary Science 17, 303-318.

Solovieva, N., Klimaschewski, A., Self, A.E., Jones, V.J., Andrén, E., Andreev, A.A., Hammarlund, D., Lepskaya, E.V., Nazarova, L., 2015. Holocene environmental history of a small coastal lake from north-eastern Kamchatka Peninsula. Global and Planetary Change 134, 55-66.
Stroeven, A.P., Hättestrand, C., Kleman, J., Heyman, J., Fabel, D., Fredin, O., Goodfellow, B.W., et al., 2016. Deglaciation of Fennoscandia. Quaternary Science Reviews 147, 91-121.

Subetto, D.A., 2009. Lake Sediments: Palaeolimnological Reconstructions. Scientific Monograph. HSPU of Russia, Saint Petersburg.

Subetto, D.A., Davydova, N.N., Rybalko, A.E., 1998. Contribution to the lithostratigraphy and history of Lake Ladoga. Palaeogeography, Palaeoclimatology, Palaeoecology 140, 113-119.

Subetto, D.A., Davydova, N.N., Sapelko, T.V., Wohlfarth, B., Wastegård, S., Kuznetsov, D.D., 2003. The climate of the North-West of Russia at the turn of the Pleistocene and Holocene. Proceedings of the Russian Academy of Sciences. Geography 5, 80-91.

Subetto, D.A., Davydova, N.N., Wohlfarth, B., Arslanov, Kh.A., 1999. Litho-, bio- and chronostratigraphy of lake sediments on the Karelian Isthmus at the boundary of the Late PleistoceneHolocene. Proceedings of the Russian Geographical Society 131, 56-69.

Subetto, D.A, Nazarova, L.B., Pestryakova, L.A., Syrykh, L.S., Andronikov, A.V., Biskaborn, B., Diekmann, B., Kuznetsov, D.D., Sapelko, T.V., Grekov, I.M., 2017. Palaeolimnological studies in Russian Northern Eurasia: A review. Contemporary Problems of Ecology 4, 327-335.

Subetto, D.A., Wastegård, S., Sapelko, T.V., Wohlfarth, B., Davydova, N.N. 2001. The first findings of volcanic ash (12 000 calendar years) in the lake sediments on the Karelian Isthmus, NW Russia. Proceedings of the Russian Geographical Society 133, 69-76.

Subetto, D.A., Wohlfarth, B., Davydova, N.N., Sapelko, T.V., Wastegård, S., Possnert, G., Persson, T., Khomutova, V.I., 2002. Climate and environment on the Karelian Isthmus, northwestern Russia, 13 000-9 000 cal. Yrs BP. Boreas 31, 1-19.

Svendsen, J.I., Astakhov, V.I., Bolshiyanov, D. Yu., Demidov, I., Dowdeswell, J.A., Gataullin, V., Hjort, C., et al., 1999. Maximum extent of the Eurasian ice sheets in the Barents and Kara Sea region during the Weichselian. Boreas 28, 234-242.

Syrykh, L., Nazarova, L., Subetto, D., Drosenko, D., Frolova, L., 2014. Multy-proxy reconstruction of climate and environment on the Karelian Isthmus, northwestern Russia. European General Assembly. 2014. Geophysical Research Abstracts 16, EGU2014-954.

Syrykh, L.S., Nazarova, L.B., Herzschuh, U., Subetto, D.A., Grekov, I.M., 2017. Reconstruction of palaeoecological and palaeoclimatic conditions of the Holocene in the south of the Taimyr according to an analysis of lake sediments. Contemporary Problems of Ecology 10, 363-369.

Syrykh, L.S., Nazarova, L.B., Subetto, D.A., 2015. Preliminary data on the development climate in the territory of the Karelian Isthmus during the Holocene by the results of Chironomidae and lithological analyses. [In Russian.] Proceedings of Karelian research centre of RAS (Limnology) 5, 53-59.

Szeroczyńska, K., Sarmaja-Korjonen, K., 2007. Atlas of Subfossil Cladocera from Central and Northern Europe. Friends of the Lower Vistula Society, Swiecie.

ter Braak, C.J.F., 1995. Ordination. In: Jongman, R.H.G., ter Braak, C.J.F., van Tongeren, O.F.R. (Eds.), Data Analysis in Community and Landscape Ecology. Cambridge University Press, Cambridge, pp. 69-173.

ter Braak, C.J.F., Prentice, I.C., 1988. A theory of gradient analysis. Advances in Ecological Research 18, 271-317.

ter Braak, C.J.F., Šmilauer, P., 2002. CANOCO Reference Manual and CanoDraw for Windows User's Guide: Software for Canonical Community Ordination (Version 4.5). Microcomputer Power, Ithaca. 
The National Atlas of Russia. 2006.Vol. 2: Nature and Ecology. Kartografia, Moscow. [In Russian.]

Thienemann, M., Kusch, S., Vogel, H., t Ritter, B., Schefuß, E., Rethemeyer J., 2019. Neoglacial transition of atmospheric circulation patterns over Fennoscandia recorded in Holocene Lake Torneträsk sediments. Boreas 48, 287-298.

Tiljander, M., Saarnisto, M., Ojala, A.E.K., Saarinen, T., 2003. A 3000-year palaeoenvironmental record from annually laminated sediment of Lake Korttajärvi, central Finland. Boreas 26, 566-577.

Trifonova, I.S., Afanasiev, A.L., Rusanov, A.G., Stanislavskaya, E.V., 2014. Plant communities of the lakes in the Central part of Karelian Isthmus as indicators of their ecological status. Proceedings of the Samara Scientific Center RAS 16, 1034-1038.

Väliranta, M., Weckström, J., Siitonen, S., Seppä, H., Alkio, J., Juutinen, S., Tuittila, E.-S., 2011. Holocene aquatic ecosystem change in the boreal vegetation zone of northern Finland. Journal of Paleolimnology 45, 339-352.

Velle, G., Brooks, S.J., Birks, H.J.B., Willasen, E., 2005. Chironomids as a tool for inferring Holocene climate: an assessment based on six sites in southern Scandinavia. Quaternary Science Reviews 24, 1429-1462.

Walker, M.J.C., Björck, S., Lowe, J.J., Cwynar, L.C., Johnsen, S., Knudsen, K.-L., Wohlfarth, B. INTIMATE group, 1999. Isotopic 'events' in the GRIP ice core: A stratotype for the late Pleistocene. Quaternary Science Reviews 18, 1143-1150.

Wanner, H., Beer, J., Bütikofer, J., Crowley, T.J., Cubasch, U., Flückigere, J., Goosse, H., Grosjean, M., Joos, F., Kaplanh,
J.O., Küttel, M., Müller, S.A., Prentice, C., Solomina, O., Stockerg, T.F., Tarasov, P., Wagner, M., Widmannm, M., 2008. Mid to late Holocene climate change: an overview Quaternary Science Reviews 27, 1791-1828.

Wastegard, S., Wohlfarth, B., Subetto, D.A., Sapelko, T.V., 2000. Extending the known distribution of the Youger Dryas Vedde Ash into north-western Russia. Journal of Quaternary Science 15, 581-586.

Weckström, J., Seppä, H., Korhola, A., 2010. Climatic influence on peatland formation and lateral expansion dynamics in subarctic Fennoscandia. Boreas 39, 761-769.

Wiederholm, T., 1983. Chironomidae of the holarctic region, keys and diagnoses. Part 1-Larvae. Entomologica Scandinavica Supplement $19,1-457$.

Wohlfarth, B., Lacourse, T., Bennike, O., Subetto, D., Tarasov, P., Demidov, I., Filimonova, L., Sapelko, T., 2007. Climatic and environmental changes in north-western Russia between 15,000 and 8000 cal yr BP: A review. Quaternary Science Reviews 26, 1871-1883.

Yu, G., Harrison, S.P., 1995. Holocene changes in atmospheric circulation patterns as shown by lake status changes in northern Europe. Boreas 24, 260-268.

Zeileis, A., Kleiber, C., Kraemer, W., Hornik, K., 2003. Testing and dating of structural changes in practice. Computational Statistics and Data Analysis, 44, 109-123.

Zeileis, A., Leisch F., Hornik, K., Kleiber, C., 2002. Strucchange: An R Package for Testing for structural change in linear regression models. Journal of Statistical Software 7, 1-38. 